\title{
Domestic Surveillance for International Terrorists: Presidential Power and Fourth Amendment Limits
}

\author{
by Richard Henry Seamon *
}

This article examines the recently disclosed, presidentially authorized program of warrantless electronic surveillance by the National Security Agency (NSA). Critics of the program say it violates the Foreign Intelligence Surveillance Act of 1978 (FISA) and the Fourth Amendment. Supporters counter that it falls within the President's congressionally irreducible power to protect national security and within the relaxed Fourth Amendment governing national security searches. This article focuses on an aspect of the controversy to which neither critics nor supporters have paid much attention: the connection between the issues of whether the NSA program violates FISA and whether it violates the Fourth Amendment. The article concludes that the President can authorize surveillance that violates FISA when such surveillance "outside FISA" is reasonably necessary to respond to a genuine national security emergency. That same emergency will ordinarily bring the surveillance within the exigent circumstances doctrine of the Fourth Amendment, as modified by the special needs doctrine. This overlap between presidential power to ignore an Act of Congress and to act free of traditional Fourth Amendment constraints is not mere coincidence. Both the separation of powers doctrine and Fourth Amendment doctrine limit executive power but carve out an area in which the President may act free of ordinary constraints when necessary to protect the nation. It is hoped that the analysis underlying this conclusion is more nuanced (and stakes out a more moderate position) than that offered by most critics and supporters of the NSA program. The analysis may, therefore, supply a legal foundation for principled and politically feasible legislative reform. In any event, the analysis offered here also informs the broad, ongoing debate over the proper roles of Congress and the federal courts in enforcing the Fourth Amendment.

\footnotetext{
"Professor, University of Idaho College of Law. I thank William C. Banks, Louis Fisher, Ken Gormley, Orin S. Kerr, David S. Kris, Timothy Lynch, Judge Richard A. Posner, Andrew M. Siegel, and Christopher Slobogin for helpful comments on drafts of this article.
} 
introduction

I. The NSA Program of Domestic Surveillance for International Terrorists.... 6

II. Presidential Power to Conduct Domestic, Electronic Surveillance for National Security Purposes Within Fourth Amendment Constraints.

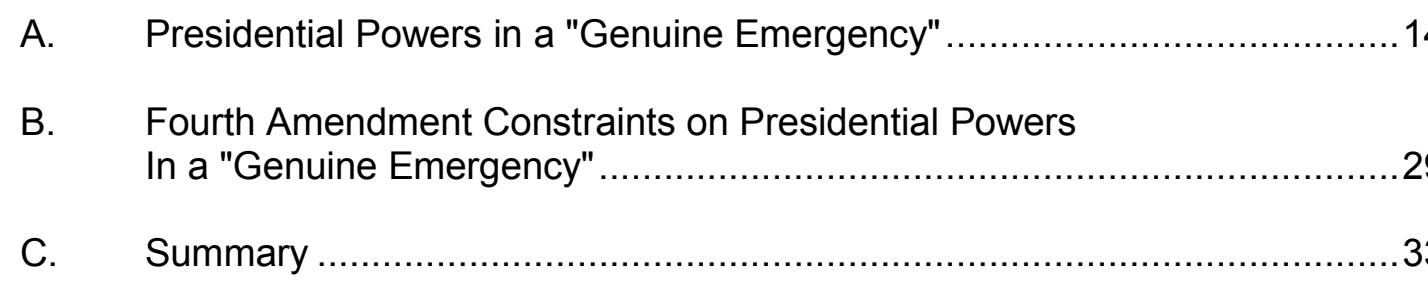
33

III. Analysis of the NSA Program As an Exercise of the President's Genuine National Security Emergency Powers

A. Whether the NSA Program Falls Within the President's Power Even Though the Program Violates FISA.

B. Whether the NSA Program Violates the Fourth Amendment Because Surveillance Under the Program Occurs Without a Warrant or Traditional Probable Cause... 39

IV. Conclusion 47

Introduction

The President has been spying on Americans again. ${ }^{1}$ The current domestic spying program began right after $9 / 11$ and is conducted by the National Security Agency (NSA) for the

\footnotetext{
${ }^{1}$ Elizabeth B. Bazan \& Jennifer K. Elsea, Congressional Research Service, Presidential Authority to Conduct Warrantless Electronic Surveillance to Gather Foreign Intelligence Information (Jan. 5, 2006), at 1-2 [hereinafter CRS Report on Warrantless Surveillance], available at http://www.fas.org/sgp/crs/intel/m010506.pdf; James Risen \& Eric Lichtblau, Bush Lets U.S. Spy on Callers Without Courts, N.Y. TIMES, Dec. 16, 2005, at A1. This is not the first time that a U.S. President has used electronic surveillance to spy on Americans supposedly for national security reasons. Indeed, the practice goes back at least to Franklin D. Roosevelt, as the Church Committee disclosed in the 1970s. The Church Committee's revelations led to enactment of the Foreign Intelligence Surveillance Act, which is at the center of the current controversy. See Margaret Ebrahim, Warrantless Surveillance Debated during Ford Term: The Dispute Was Similar to the Current One Between Congress and the White House, PHILA. INQUIRER, Feb. 4, 2006, at A10, 2006 WLNR 2001538 (reporting that 200 pages of historic records "reflect a remarkably similar dispute between the White House and Congress fully three decades before President Bush's acknowledgement [in December 2005] that he authorized wiretaps without warrants of some Americans in terrorism investigations"); Scott Shane, For Some, Spying Controversy Recalls a Past Drama, N.Y. TIMES, Feb. 6, 2006, at A18 (comparing post 9/11 domestic surveillance program to surveillance programs that came to light in the 1970s and that led to legislative reform); Karen Dorn Steele, Yakima's Spy Outpost: Secrecy Shrouds NSA Installation Monitoring West Coast, SPOKESMAN-REVIEW (Spokane, WA), Feb. 5, 2006, at 1A ("The current NSA controversy is a flashback to the 1960s and '70s, when NSA, the CIA and the FBI were caught illegally spying on journalists, congressmen, and peace activists.").
} 
purpose of detecting and preventing eventuation of threats posed by international terrorists. ${ }^{2}$

The NSA program has been thought to raise two issues. ${ }^{3}$ One issue is whether the program violates the Foreign Intelligence Surveillance Act of 1978 (FISA). ${ }^{4}$ This FISA issue arises because the NSA program involves electronic surveillance (e.g., wiretapping) that is subject to FISA but has occurred without FISA compliance. The second issue is whether the program violates the Fourth Amendment. ${ }^{5}$ This Fourth Amendment issue arises because surveillance under the NSA program occurs without prior judicial authorization or traditional probable cause. ${ }^{6}$ Public debate on the surveillance program is correct to distinguish the FISA issue from the Fourth Amendment issue; they require different analyses. Public debate has not, however, paid enough attention to the connection between the FISA issue and the Fourth Amendment issue. ${ }^{7}$ This article attempts to fill the gap.

2 See ACLU v. NSA, No. 06-CV-10204, 2006 WL 2371463, at *1 (E.D. Mich. Aug. 17, 2006); Letter from Alberto R. Gonzales, Attorney General of U.S., to Sen. Arlen Specter 1 (Feb. 28, 2006) [hereinafter Attorney General Letter of Feb. 28, 2006] (stating that the President authorized the "Terrorist Surveillance Program" in October 2001, before signing the USA PATRIOT Act), available at http://www.fas.org/irp/congress/2006_hr/022806gonzales.pdf; George W. Bush, President of the U.S., President's Radio Address (Dec. 17, 2006), available at

http://www.whitehouse.gov/news/releases/2005/12/20051217.html (President states that he authorized the NSA program "[i]n the weeks following the terrorist attacks on our nation").

${ }^{3}$ See, e.g., Jerry Crimins, NSA Wiretaps Debated at U of Chicago, CHI. DAILY L. BULL. 1 (Feb. 1, 2006) (reporting that in public debate Professor Geoffrey R. Stone said the "two primary arguments" against current program are that it violates the Fourth Amendment and the Foreign Intelligence Surveillance Act). ${ }^{4} 50$ U.S.C. $\S \S 1801-1862$. For an example of the argument that the program violates FISA, see, e.g., Beth Nolan et al., On NSA Spying: A Letter to Congress, N.Y. REV. OF BoOKS, Feb. 9, 2006, at _. For a description of FISA, see Richard Henry Seamon \& William Dylan Gardner, The Patriot Act and the Wall Between Foreign Intelligence and Law Enforcement, 28 HARV. J.L. \& PUB. POL'Y 319, 337-58 (2005). ${ }^{5}$ U.S. CONST. amend. IV:

The right of the people to be secure in their persons, houses, papers, and effects, against unreasonable searches and seizures, shall not be violated, and no Warrants shall issue, but upon probable cause, supported by Oath or affirmation, and particularly describing the place to be searched, and the persons or things to be seized.

${ }^{6}$ See Wartime Executive Power and the NSA's Surveillance Authority II: Hearing Before the Sen. Comm. On the Judiciary, 109th Cong. _ (Feb. 28, 2006) [hereinafter Senate Hearing of Feb. 28, 2006] (testimony of Ken Gormley, Professor of Constitutional Law, Duquesne University) (arguing that "the program directly collides with rights of American persons under the Bill of Rights, specifically the Fourth Amendment"), available at http://judiciary.senate.gov/testimony.cfm?id=1770\&wit_id=5228.

${ }^{7}$ The connection goes unexplored, for example, in the only published decision so far to address the constitutionality of the program. See ACLU v. NSA, 2006 WL 2371463, at *17-*27 (holding the Program unconstitutional). 
The article reaches a twofold conclusion. First, the President may defy FISA in certain circumstances by authorizing electronic surveillance that is subject to FISA but that occurs without compliance with FISA's standards and procedures. ${ }^{8}$ Furthermore, the very same circumstances that justify such surveillance "outside FISA"9 can often cause the surveillance to satisfy the Fourth Amendment even though conducted without a warrant or traditional probable cause. $^{10}$ By the same token, when circumstances do not justify surveillance outside FISA, the government's violation of FISA presumptively violates the Fourth Amendment. ${ }^{11}$

The circumstances that excuse compliance with both FISA and traditional Fourth Amendment requirements are ones that constitute a genuine national security emergency. Precedent suggests that in a "genuine emergency" the President has inherent and congressionally irreducible power to respond to national security threats. ${ }^{12}$ Although at first blush the Court's recent decision in Hamdan v. Rumsfeld ${ }^{13}$ might be understood to cast doubt on the existence of such plenary presidential power, on closer examination Hamdan actually supports its existence. A genuine national security emergency may not only justify Presidential action that defies an Act of Congress; a genuine emergency may create exigent circumstances justifying searches and seizures without the usual Fourth Amendment requirements of probable cause and prior judicial approval. In the absence of a "genuine emergency" that necessitates defiance of FISA, however, the President's failure to comply with FISA should be presumed to

\footnotetext{
${ }^{8}$ See infra notes _- _ and accompanying text.

${ }^{9}$ This article follows $\bar{a}$ convention of current public debate by using the phrase "surveillance outside FISA" to describe electronic surveillance that is subject to FISA but authorized by the President to be carried out without complying with FISA. See, e.g., CRS Report on Warrantless Surveillance, supra note _, at 14 (referring to "the President's authorization of electronic surveillance to acquire foreign intelligence information outside the FISA framework"); United States Department of Justice, Legal Authorities Supporting the Activities of the National Security Agency Described by the President (Jan. 19, 2006), at 18 (referring to "surveillance outside the procedures set forth in FISA") [hereinafter DOJ White Paper]; id. at 19 n.6 (referring to communications intercepted "outside FISA procedures").

${ }_{11}^{10}$ See infra notes ___ and accompanying text.

${ }^{11}$ See infra notes - - and accompanying text.

12 See Hamdi v. Rumsfeld, 542 U.S. 507, 552 (2004) (Souter, J., concurring in part, dissenting in part, and concurring in the judgment) (suggesting that government could detain a citizen in a "genuine emergency," even if that detention violated an Act of Congress); see also infra notes ____ and accompanying text.

13126 S. Ct. 2749 (2006).
} 
violate the Fourth Amendment because FISA was designed by Congress, in collaboration with the Executive branch, to implement the Fourth Amendment.

The President's power to authorize surveillance outside FISA in a genuine national security emergency does not justify the current NSA surveillance program. The program's very status as an ongoing, broad "program" prevents it from falling within the President's "genuine emergency" power. The genuine emergency power is limited in scope and duration when it is exercised against the backdrop of legislation, such as FISA, that is a generally valid regulation of the President's power to conduct domestic surveillance for national security purposes. For example, the President may well have had broad power to conduct surveillance outside FISA in the days and weeks immediately after the terrorist attacks on September 11, 2001. That power subsided, however, as time and a still-functioning civil government permitted the President to consult Congress on the appropriate scope of surveillance powers. Today, the President may still have power to authorize surveillance outside FISA. That power, however, exists only when FISA's shortcomings make surveillance outside FISA reasonably necessary for national security purposes. In sum, the President's "genuine emergency" power no longer supports a broad surveillance program that violates a generally valid Act of Congress.

This analysis underlying this conclusion unfolds in three steps. Part I briefly describes publicly available information on NSA's domestic surveillance program and the legal controversy over it. Part II discusses the connection between the President's power to authorize electronic surveillance outside FISA and Fourth Amendment limits on that power. Principles that emerge from that discussion are applied to the NSA program in Part III of the article. Part III concludes that, although in exceptional circumstances the President can authorize surveillance that violates FISA and does not satisfy customary Fourth Amendment requirements, the current NSA program of routine, widespread surveillance exceeds the President's power and violates the Fourth Amendment. This conclusion reflects a more nuanced analysis (and stakes out a more moderate position) than is offered by most opponents and supporters of the NSA program. 
I hope, for that reason, that the analysis offered here supplies a legal foundation for principled and politically feasible legislative reform. ${ }^{14}$

I. The NSA Program of Domestic Surveillance for International Terrorists International terrorists attacked the United States on September 11, $2001(9 / 11) .{ }^{15}$ Soon after 9/11, the President authorized a surveillance program to investigate those attacks and prevent future ones. ${ }^{16}$ The program is run by the National Security Agency ("NSA") and involves electronic surveillance, such as wiretapping telephones. ${ }^{17}$ Many details of the program remain secret. ${ }^{18}$ The government admits, however, that NSA monitors phone calls and email that are made (1) to or from the United States and a foreign country; (2) by, or to, someone whom the government has a "reasonable grounds" to believe has ties to al Qa'eda, the terrorist network responsible for the 9/11 attacks, "or an affiliated terrorist organization."19 The

${ }^{14}$ See infra notes __-_ and accompanying text (citing and discussing current commentary). I am not aware of any published scholarship examining the connection between the issue of whether the current NSA program violates FISA and the issue of whether it violates the Fourth Amendment. The connection does receive attention, however, in a recent court filing by the Center for National Security Studies and The Constitution Project. See Memorandum of the Constitution Project and the Center for National Security Studies in Response to U.S. Department of Justice's Defense of Warrantless Electronic Surveillance at 42-46, In re Warrantless Electronic Surveillance (filed Feb. 28, 2006) [hereinafter Amicus Memo, In re Warrantless Electronic Surveillance], available at http://www.cnss.org/FISC\%20Memorandum\%20(signed).PDF.

${ }^{15}$ See, e.g., Elisabeth Bumiller with David E. Sanger, A Somber Bush Says Terrorism Cannot Prevail, N.Y. TIMES, Sept. 12, 2001, at A1.

${ }^{16}$ See Attorney General Letter of Feb. 28, 2006, supra note _, at 1 (stating that the President authorized the "Terrorist Surveillance Program" about which Gonzales previously testified before Congress in October 2001, before signing the USA PATRIOT Act).

${ }^{17}$ Wartime Executive Power and the NSA's Surveillance Authority I: Hearing Before the Sen. Comm. On the Judiciary, $109^{\text {th }}$ Cong.. _ (Feb. 6, 2006) [hereinafter Senate Hearing of Feb. 6, 2006] (testimony of Alberto R. Gonzales, Attorney General of U.S.) ("[T]his program is administered by career professionals at NSA."), available at http://judiciary.senate.gov/testimony.cfm?id=1727\&wit_id=3936; id. at (testimony of Attorney General Gonzales) ("[T]he NSA did not commence the kind of electronic surveillance which I am discussing here today prior to the president's authorization.").

${ }^{18}$ Senate Hearing of Feb. 6, 2006, supra, note__, at _ (testimony of Attorney General Gonzales) ("Many operational details of our intelligence activities remain classified and unknown to our enemy.").

${ }^{19}$ Senate Hearing of Feb. 6, 2006, supra note _, at _ (testimony of Attorney General Gonzales) (stating that "only international communications are authorized for interception" -- i.e., "communications between a foreign country and this country" -- and that surveillance is triggered "only when a career professional at the NSA has reasonable grounds to believe that one of the parties to a communication is a member of agent of AI Qaida or an affiliated terrorist organization"); DOJ White Paper, supra note 5, at ("The President has acknowledged that, to counter this [al Qaeda] threat, he has authorized the NSA to intercept international communications into and out of the United States of persons linked to al Qaeda or related terrorist organizations."). 
government also seemingly admits that some of this surveillance is subject to the Foreign Intelligence Surveillance Act of 1978 ("FISA") but has not been conducted in compliance with FISA's requirements. ${ }^{20}$ This admission means that the NSA program may be illegal on either of two grounds (or both).

First, the NSA program may violate FISA. FISA prescribes "the exclusive means by which electronic surveillance [for foreign intelligence purposes] ... may be conducted" in the United States. ${ }^{21}$ FISA's legislative history confirms that Congress intended FISA to govern all domestic electronic surveillance for foreign intelligence purposes. ${ }^{22}$ Congress made FISA

${ }^{20}$ See Press Briefing by Attorney General Alberto Gonzales and General Michael Hayden, Principal Deputy Director for National Intelligence (Dec. 19, 2006) (statement of Attorney General Gonzales) ("[l]in terms of legal authorities, the Foreign Intelligence Surveillance Act provides -- requires a court order -before engaging in this kind of surveillance that I've just discussed and the President announced on Saturday, unless ... otherwise authorized by statute or by Congress.") [hereinafter Attorney General Press Briefing of Dec. 2005], available at http://www.whitehouse.gov/news/releases/2005/12/print/20051219-1.html; cf. DOJ White Paper, supra note _ , at 17 n.5 ("To avoid revealing details about the operation of the program, it is assumed for purposes of this paper that the activities described by the President constitute 'electronic surveillance,' as defined by FISA, 50 U.S.C. § 1801(f)."); Letter from William E. Moschella, Assistant Attorney General, U.S. Dept of Justice, to Hon. F. James Sensenbrenner, Jr., Chairman, U.S. House of Rep. Judiciary Comm., encl. at 10 (Mar. 24, 2006) [hereinafter Moschella Letter of Mar. 24, 2006] (stating that DOJ Whitepaper "assumes, solely for purposes of that analysis, that the targeted interception of international communications authorized under the President's Terrorist Surveillance Program would constitute 'electronic surveillance' as defined in FISA, but Department "cannot confirm whether that is actually the case without disclosing sensitive classified information"), available at http://www.fas.org/irp/agency/doj/fisa/doj032406.pdf.

${ }^{21} 18$ U.S.C. $\S 2511(2)(\mathrm{f})$. Section $2511(2)(\mathrm{f})$ also authorizes "electronic surveillance ... and the interception of domestic wire, oral, and electronic communications" to occur under Title III of the Omnibus Crime Control and Safe Streets Act of 1968 ("Title III") and under Chapter 121 of Part I of Title 18, 18 U.S.C. $\S \S 2701-2712$. Title III authorizes wiretaps for criminal investigations, see 18 U.S.C. $\S \S 2516$ \& 2518(3)(a) (wiretap order requires probable cause that individual targeted for the wiretap is involved in one of enumerated offenses), and Chapter 121 concerns access to stored electronic communications, such as email messages for the investigation of criminal offenses. See 18 U.S.C. § 2701(a) (generally prohibiting unauthorized access to "a wire or electronic communication while it is in electronic storage" in a "a facility through which an electronic communication service is provided"); id. $\S 1803(a)$ \& (d) (authorizing access to wire or electronic communications and customer records for an "offense under investigation" and for "an ongoing criminal investigation"). See generally Orin S. Kerr, A User's Guide to the Stored Communications Act, and a Legislator's Guide to Amending It, 72 GEO. WASH. L. REV. 1208 (2004) (explicating Chapter 121 and suggesting legislative revisions). The government has not claimed that either Title III or Chapter 121 supports the current NSA surveillance program, leaving FISA as the "exclusive" means of surveillance, under $\S 2511(2)(f)$. In addition to the exclusivity provision in Section 2511(2)(f), FISA provides: "A person is guilty of an offense if he intentionally engages in electronic surveillance under color of law except as authorized by statute." 50 U.S.C. § 1809(a)(1).

22 The exclusivity provision in Section $2511(2)(\mathrm{f})$ of FISA replaced a provision in Title III stating that Title III did not limit the President's power to "take such measures as he deems necessary" to protect national security. Omnibus Crime Control and Safe Streets Act of 1968, Pub. L. No. 90-351, tit. III, § 802, 82 Stat. 
exclusive to stop executive abuses exposed in the 1970s through efforts such as the Church Committee investigations. ${ }^{23}$ The Church Committee revealed that Presidents since Franklin D. Roosevelt had authorized warrantless surveillance of Americans. ${ }^{24}$ Although Presidents claimed "inherent" power to authorize this surveillance for "national security" purposes, the surveillance often targeted people merely because of their political views. ${ }^{25}$ By enacting FISA in 1978, Congress intended to "prohibit the President, notwithstanding any inherent powers," from

214 (1968), repealed by Foreign Intelligence Surveillance Act of 1978, Pub. L. No. 95-511, § 201(c), 92 Stat. 1797. Because the prior provision was designed to preserve the President's "inherent" constitutional authority, if any, to authorize surveillance that was not authorized by any statute, its repealer reinforces Congress's intent to eliminate the President's inherent power in this area, to the extent Congress was able to do so. So does Congress's enactment of $\S 2511(2)(\mathrm{f})$ instead of proposed provisions that, unlike $\S 2511(2)(\mathrm{f})$, continued to recognize possible inherent presidential power to conduct national security surveillance without statutory authorization. See S.3197, $94^{\text {th }}$ Cong. $\S 2528$, reprinted in Hearings on S. 743, S. 1888, S. 3197 Before the Subcomm. On Criminal Laws and Procedure of the Sen. Comm. on the Judiciary, $94^{\text {th }}$ Cong 134 (1976) (bill provision stating that legislation proposed in the bill would not "limit the constitutional power of the President to order electronic surveillance" for national security purposes); H. Conf. Rep. No. 95-1270, at 35 (1978) (observing that House version provided that FISA and Title III would be "the exclusive statutory means" by which President could conduct surveillance, but Conference selected Senate version, "which omits the word 'statutory"'); Ira S. Shapiro, The Foreign Intelligence Surveillance Act: Legislative Balancing of National Security and the Fourth Amendment, 15 HARV. J. ON LEGIS. 119, 123 n.11 (1977) (quoting later version of S. 3197, 94 ${ }^{\text {th }}$ Cong. (1976), in which Senate Intelligence Committee narrowed the bill so that it referred to President's possible constitutional authority to conduct surveillance 'if the facts and circumstances giving rise to the acquisition are so unprecedented and potentially harmful to the Nation that they cannot reasonably be said to have been within the contemplation of Congress"). Other legislative history expresses Congress's intent in FISA to eliminate the President's inherent power to conduct national security surveillance. See S. REP. No. 95-604, pt. I, at 6 (1978) (bill enacted as FISA "recognizes no inherent power of the President in this area"); id. at 64 ("As to methods of acquisition which come within the definition of 'electronic surveillance' in this bill, the Congress has declared that this statute, not any claimed presidential power, controls."); H.R. REP. No. 951283, pt. 1, at 24 (1976) ("[E]ven if the President has the inherent authority in the absence of legislation to authorize warrantless electronic surveillance for foreign intelligence purposes, Congress has the power to regulate the conduct of such surveillance by legislating a reasonable procedure, when then becomes the exclusive means by which such surveillance may be conducted."); see also Senate Hearing of Feb. 6, 2006, supra note _, at _ (testimony of Attorney General Gonzales) ("There is no question, if you look at the legislative history [of FISA] ..., that Congress intended to try to limit whatever president's inherent authority existed.").

${ }^{23}$ See, e.g., S. REP. No. 95-604, at 8 (1977) (bill that became FISA "is designed .... to curb the practice by which the Executive Branch may conduct warrantless electronic surveillance on its own unilateral determination that national security justifies it"); see also Richard Henry Seamon \& William Dylan Gardner, The Patriot Act and the Wall Between Foreign Intelligence and Law Enforcement, 28 HARV. J.L. \& PUB. POL'Y 319, 336-37 \& nn. 66-71 (2005) (discussing and citing relevant legislative history).

${ }_{24}$ See, e.g., S. REP. No. 95-604, at 7-8 (1977).

${ }^{25}$ See, e.g., id. at 8. 
conducting domestic electronic surveillance for foreign intelligence purposes without complying with FISA. ${ }^{26}$

Ever since the post-9/11 NSA program of domestic surveillance came to light in late 2005, however, President George W. Bush has claimed both statutory and constitutional power to conduct surveillance "outside FISA." The statutory power, he contends, comes from post9/11 legislation entitled the "Authorization for the Use of Military Force" ("AUMF"). ${ }^{27}$ He also claims "inherent constitutional authority as Commander in Chief and sole organ for the Nation in foreign affairs." 28

${ }^{26}$ See note _ supra (citing legislative history of FISA indicating Congress's intent that FISA be the exclusive source of executive branch power to conduct electronic surveillance for foreign intelligence information); see also H.R. REP. No. 95-1283, pt. I, at (1978) ("[D]espite any inherent power of the President to authorize warrantless electronic surveillances in the absence of legislation, by this bill [and Title III ..., Congress will have legislated with regard to electronic surveillance in the United States, that legislation with its procedures and safeguard prohibit the President, notwithstanding any inherent powers, from violating the terms of that legislation."). Section 111 of FISA makes clear that Congress intended FISA to apply -- to the exclusion of the President's inherent powers -- even during wartime. Section 111 says, "[T]he President, through the Attorney General, may authorize electronic surveillance without a court order ... to acquire foreign intelligence information for a period not to exceed fifteen calendar days following a declaration of war by the Congress." 50 U.S.C. $§ 1811$. I thank Louis Fisher for pointing out to me the significance of this provision. E-mail from Louis Fisher, Senior Specialist in Separation of Powers, Congressional Research Service, Library of Congress, to Richard Henry Seamon, Professor of Law, University of Idaho college of Law (July 12, 2006 6:59 AM) (on file with author).

${ }^{27}$ See, e.g., Attorney General Press Briefing of Dec. 2005, supra note _ ("Our position is that the authorization to use force, which was passed by the Congress in the days following September $11^{\text {th }}$, constitutes th[e] other authorization [to which FISA refers] ... to engage in this kind of signals intelligence."); Senate Hearing of Feb. 6, 2006, supra note _, at _ (testimony of Attorney General Gonzales) ("[T]he resolution authorizing the use of military force is exactly the sort of later statutory authorization contemplated by FISA's safety valve."); see also Authorization for Use of Military Force, Pub. L. No. 107-40, § 2(a), 115 Stat, 224 (Sept. 18, 2001), reprinted in 50 U.S.C. § 1541 note (Authorization for Use of Military Force).

${ }^{28}$ See Senate Hearing of Feb. 6, 2006, supra note _ , at _ (testimony of Attorney General Alberto R. Gonzales) (President's "inherent authorities" under Constitution "include the power to spy on enemies like Al Qaida without prior approval from other branches of government"); DOJ White Paper, supra note _, at 1 (to the same effect). 
The President's reliance on the AUMF is weak. ${ }^{29}$ The AUMF in relevant part authorizes the President to "use all necessary and appropriate force against those nations, organizations, or persons he determines planned, authorized, committed, or aided the [9/11] terrorist attacks." ${ }^{30}$ The problem is that, in context, the term "force" cannot be reasonably construed to authorize domestic electronic surveillance. Not coincidentally, members of Congress have almost universally rejected the President's reliance on the AUMF. ${ }^{31}$ Because the AUMF does not authorize the NSA program, the President's power to authorize the NSA program depends on his constitutional powers, as validly reduced by FISA. $^{32}$

${ }^{29}$ See, e.g., Senate Hearing of Feb. 28, 2006, supra note _, at __ (prepared statement of Harold Hongju Koh, Dean and Gerard C. \& Bernice Latrobe Smith Professor of International Law, Yale Law School) (President's reliance on AUMF "does not pass the 'straight face' test"), available at http://judiciary.senate.gov/testimony.cfm?id=1770\&wit_id=3938; American Bar Association, Task Force on Domestic Surveillance in the Fight Against Terrorism, Report 5 (Feb. 2006) ("There is nothing in either the language of the AUMF or its legislative history" to support NSA surveillance program) [hereinafter ABA Task Force Report on NSA Surveillance], available at http://www.abanet.org/op/greco/memos/aba_house302-0206.pdf; see also ACLU v. NSA, 2006 WL 2371463 , at *23- ${ }^{*} 24$ (holding that NSA program is not authorized by AUMF). But see DOJ White Paper, supra note _, at 10 ("The AUMF confirms and supplements the President's inherent power to use warrantless surveillance against the enemy in the current armed conflict.") (capitalization altered); Andrew C. McCarthy et al., NSA's Warrantless Surveillance Program: Legal, Constitutional, and Necessary 60-63 in THE FEDERALIST SOCIETY, TERRORIST SURVEILLANCE AND THE CONSTITUTION (undated) (arguing that AUMF supports NSA program), http://www.fed-soc.org/pdf/terroristsurveillance.pdf Letter from Robert Alt, Fellow in Legal and International Affairs, John M. Ashbrook Center for Public Affairs, to Hon. James Sensenbrenner, Jr., 2 (Feb. 2006) ("[T]he scope of the President's electronic surveillance program ... is consistent with the scope of the AUMF's authorization of the use of force."), available at http://www.ashbrook.org/publicat/dialogue/alt judiciary.html.

${ }^{30}$ AUMF § 2(a), 115 Stat. 224, reprinted in 50 U.S.C. § 1541 note (Authorization for Use of Military Force).

${ }^{31}$ See, e.g., Senate Hearing of Feb. 6, 2006, supra note _ , at __ (statement of Sen. Specter) (stating that in his opinion AUMF does not authorize the NSA program). But cf. Letter from Sen. Pat Roberts to Sens. Arlen Specter and Patrick J. Leahy 17 (Feb. 3, 2006) (defending surveillance program primarily based on president's inherent powers but stating: "I do not discount the legal arguments of the Department of Justice concerning the [AUMF]."), available at http://www.fas.org/irp/congress/2006_cr/roberts020306.pdf.

${ }^{32}$ See infra notes ___ and accompanying text. 
In addition to violating FISA, the NSA program may violate the Fourth Amendment. ${ }^{33}$

The Fourth Amendment applies to some electronic surveillance, because electronic surveillance can constitute a "search" within the meaning of the Fourth Amendment. ${ }^{34}$ Reflecting a traditional Fourth Amendment requirement, FISA ordinarily requires the government to get a court order before conducting electronic surveillance. ${ }^{35}$ To get a court order, the government must show "probable cause" that the target of the surveillance is a foreign power or agent of a foreign power. ${ }^{36}$ FISA's requirement for a court order based on probable cause, combined with the other FISA requirements, has led courts to reject Fourth Amendment challenges to surveillance that complies with FISA. ${ }^{37}$ By the same token, surveillance outside FISA may

${ }^{33}$ U.S. CONST. amend. IV; see, e.g., William Banks, NSA Eavesdropping and the Fourth Amendment, JURIST-FORUM, Mar. 8, 2006 (arguing that "this domestic spying violates the Fourth Amendment"), http://jurist.law.pitt.edu/forumy/2006/03/nsa-eavesdropping-and-fourth-amendment.php; Complaint for Declaratory and Injunctive Relief at 2 \ 3 \& 59 \ 193, American Civil Liberties Union v. National Security Agency, Civ. No. 06-CV-10204 (E.D. Mich. filed Jan. 17, 2006) [hereinafter ACLU v. NSA] (alleging program violates Fourth Amendment), available at http://cdt.org/security/nsa/20060117aclu-complaint.pdf; Complaint at 2 \ा 2 \& 15 आ 50, Center for Constitutional Rights v. Bush, No. 06-CV-00313 (S.D.N.Y. filed Jan. 17, 2006) [hereinafter CCR v. Bush] (similar allegations), available at http://www.ccrny.org/v2/legal/govt_misconduct/docs/NSAcomplaintFINAL11706.pdf; cf. Letter from Curtis A. Bradley, Richard and Marcy Horvitz Professor of Law, Duke Univ., to Sen. Bill Frist et al. 5 (Jan. 9. 2006) [hereinafter Law Professors' Letter to Congress] (stating that program raises serious Fourth Amendment if considered to be statutorily authorized), available at http://www.cdt.org/security/20060109legalexpertsanalysis.pdf.

${ }^{34}$ See, e.g., Katz v. United States, 389 U.S. 347, 353 (1967) (holding that search occurred when government attached an electronic listening device to outside of phone booth and overhead the person speaking on the phone inside the booth); see also Osborn v. United States, 385 U.S. 323, 326-31 (1967) (rejecting constitutional challenge to government's electronic recording of conversation when government first obtained warrant authorizing the recording); Richard H. Seamon, Kyllo v. United States and the Partial Ascendance of Justice Scalia's Fourth Amendment, 79 WASH. U.L.Q. 1013, 1013-14 (2001) (discussing applicability of Fourth Amendment to technological developments in surveillance). 3550 U.S.C. $\S 1805$.

${ }^{36} / d . \S 1805(\mathrm{a})(3)(\mathrm{A})$.

${ }^{37}$ United States v. Damrah, 124 F. App'x 976, 983 ( $6^{\text {th }}$ Cir. 2005) ("FISA has uniformly been held to be consistent with the Fourth Amendment."); see, e.g., In re Sealed Case, 310 F.3d 717, 736-46 (Foreign Int. Surv. Ct. Rev. 2002) (rejecting Fourth Amendment challenge to FISA); United States v. Pelton, 835 F.2d 1067,1075 ( $4^{\text {th }}$ Cir. 1987) ("We now join the other courts of appeals that have reviewed FISA and held that the statute meets constitutional requirements."); United States v. Cavanagh, 807 F.2d 787, $790\left(9^{\text {th }}\right.$ Cir. 1987) ("FISA satisfies the constraints the Fourth Amendment places on foreign intelligence surveillance conducted by the government."); United States v. Duggan, 743 F.2d 59, 73 (2d Cir. 1984) ("We regard the procedures fashioned in DISA as a constitutionally adequate balancing of the individual's Fourth Amendment rights against the nation's need to obtain foreign intelligence information."). 
violate the Fourth Amendment precisely because it occurs without a court order ${ }^{38}$ and without meeting the other requirements of FISA, possibly including its substantive standard of "probable cause." 39

Public debate on the NSA program has centered on whether it violates FISA or the Fourth Amendment. ${ }^{40}$ The debate has not scrutinized the connection between the FISA issue and the Fourth Amendment issue. Nor was the connection detected, much less explored, in the only published court opinion so far to address a legal challenge to the NSA program. ${ }^{41}$ Indeed, the significance of the connection between the FISA issue and the Fourth Amendment issue is not obvious. In commenting on a draft of this article, Judge Richard Posner asked why this connection is important if, as this article concludes, the current NSA program violates both FISA and the Fourth Amendment. To quote Judge Posner, "If the NSA program violates FISA, what

${ }^{38}$ See Attorney General Press Briefing of Dec. 2005, supra note _ (Attorney General Gonzales stating U.S.'s position that it is not legally required to get court approval for NSA surveillance program disclosed in December 2005).

${ }^{39}$ Compare DOJ White Paper, supra note _, at 5 (stating that surveillance under NSA program requires "a reasonable basis to believe that one party to the communication is a member of al Qaeda, associated with al Qaeda or a member of an organization affiliated with al Qaeda") with Alberto R. Gonzales, Prepared Remarks for Attorney General Alberto R. Gonzales at the Georgetown University Law Center (Jan. 24, 2006) ("the standard applied [for surveillance under NSA program] - 'reasonable basis to believe' -- is essentially the same as the traditional Fourth Amendment probable cause standard."); and Moschella Letter of Mar. 24, 2006, supra note _, encl. at 2-3 (Mar. 24, 2006) (equating "reasonable basis" standard to "probable cause").

${ }^{40}$ See, e.g., Law Professors' Letter to Congress, supra note _ , at 5 (arguing that program violates FISA and "would raise serious questions under the Fourth Amendment); Senate Hearing of Feb. 28, 2006, supra note _ , at _ (testimony of Prof. Ken Gormley) (stating that NSA program violates FISA and Fourth Amendment); ABA Task Force Report on NSA Surveillance, supra note _, at 10, 13 (presenting two arguments: that "Congress did not implicitly authorize the NSA domestic spying program in the AUMF, and in fact expressly prohibited it in FISA"; and that "construing the AUMF to authorize such wiretapping would raise serious questions under the Fourth Amendment"); see also Complaint at 13-15, CCR v. Bush, supra note _ (alleging that NSA program violates, among other laws, FISA, separation of powers, and First and Fourth Amendments); Complaint at 59, ACLU v. NSA, supra note _ (alleging violations of First Amendment rights, separation of powers, and Administrative Procedure Act ("APA"), with the APA violation arising from program's violation of FISA).

${ }^{41}$ See ACLU v. NSA, 2006 WL 2371463, at *17-*27; see also Editorial, Ruling for the Law, N.Y. Times, Aug. 18, 2006, at A16 (describing decision in ACLU v. NSA as holding that NSA program violated FISA, the Fourth Amendment, and the First Amendment); cf. Editorial, A Judicial Misfire, WASH. POST, Aug. 18, 2006, at A20 (observing that opinion in ACLU v. NSA "is neither careful nor scholarly"). 
is the point of saying that therefore it also violates the Fourth Amendment?" 42 A court made the converse point in recently striking down the NSA program, stating the view that it is "irrelevant" whether the NSA program violates restrictions validly imposed by FISA because the program violates the Fourth Amendment. ${ }^{43}$

My contention, developed over the next two parts of this article, is that the NSA program violates the Fourth Amendment precisely because it violates FISA. In other words, the NSA program violates the Fourth Amendment today -- because FISA is on the books -- even though the program may very well not have violated the Fourth Amendment before FISA was enacted and might very well not violate the Fourth Amendment if FISA were repealed. Congress's enactment of a statute that is within Congress's power and that is designed to implement the Fourth Amendment alters the Fourth Amendment analysis. In this sense, Congress can affect the substance of the Fourth Amendment. Recognizing Congress's power to enact statutes that alter Fourth Amendment reasonableness illuminates linkage between the Fourth Amendment and separation of powers doctrine. In addition, an understanding of the connection informs the broader debate on the roles of legislatures and courts in enforcing the Fourth Amendment. ${ }^{44}$ II. Presidential Power to Conduct Domestic Electronic Surveillance for National Security Purposes Within Fourth Amendment Constraints

The analysis of whether the NSA program violates FISA differs from, but overlaps with, the analysis of whether the NSA program violates the Fourth Amendment. The issue of whether the program violates FISA requires a separation of powers analysis that draws a line between the President's power and Congress's power. ${ }^{45}$ The issue of whether the program violates the

\footnotetext{
${ }^{42}$ E-mail from Judge Richard Posner, U.S. Court of Appeals for the Seventh Circuit, to Richard Henry Seamon, Professor of Law, University of Idaho College of Law (July 8, 2006 8:07 pm) (on file with author); see also ACLU v. NSA, 2006 WL 2371463.

${ }^{43}$ ACLU v. NSA, 2006 WL 2371463, at *25.

${ }^{44}$ See generally Orin S. Kerr, The Fourth Amendment and New Technologies: Constitutional Myths and the Case for Caution, 102 MICH. L. REV. 801, 804 (2004) (critiquing "popular view" that courts should take a primary role in enforcing privacy threatened by technology; urging an important role for legislature); $c f$. Daniel J. Solove, Fourth Amendment Codification and Professor Kerr's Misguided Call for Judicial Deference, 74 FordhAm L. ReV. 747 (2005) (criticizing Professor Kerr's critique).

${ }^{45}$ See infra notes ____ and accompanying text.
} 
Fourth Amendment entails a reasonableness analysis that strikes a balance between governmental and individual interests. ${ }^{46}$ Despite this difference in analyses, the FISA issue and the Fourth Amendment issue overlap when it comes to identifying what the President can and cannot do.

Specifically, as discussed below in Section A, FISA is unconstitutional -- and the President can therefore disregard it -- when doing so is required by exigent circumstances of national security. ${ }^{47}$ Furthermore, electronic surveillance conducted under exigent national security circumstances will satisfy the Fourth Amendment, even if it does not meet the traditional Fourth Amendment requirements of prior judicial approval and probable cause, if, as will often be true, the surveillance falls within the exigent circumstances doctrine of Fourth Amendment law. As discussed in Section B below, however, when national security exigencies do not exist, the President's failure to comply with FISA exceeds his authority and presumptively violates the Fourth Amendment. ${ }^{48}$

The connection between the FISA issue and the Fourth Amendment issue reflects that both separation of powers doctrine and Fourth Amendment doctrine recognize plenary executive power when necessary to protect national security. The second conclusion reflects that, outside of such exceptional circumstances, both separation of powers and Fourth Amendment doctrine support legislative and judicial checks on the executive to prevent executive abuse of individual rights.

\section{A. Presidential Powers in a "Genuine Emergency"}

As noted above, the President seemingly admits that after $9 / 11$ he authorized "electronic surveillance" within the meaning of FISA without following FISA's requirements. ${ }^{49}$ As also noted above, this surveillance outside FISA is not authorized by the later-enacted AUMF (or any other

\footnotetext{
${ }^{46}$ See infra notes _____ and accompanying text.

47 See infra notes ___ _ a a a accompanying text.

48 See infra notes __- _ and accompanying text.

${ }^{49}$ See supra notes _____ and accompanying text.
} 
statute). ${ }^{50}$ Because neither the AUMF nor any other statute authorizes the surveillance, only the President's "inherent powers" can do so, and they can do so only to the extent that those inherent powers cannot validly be restricted by FISA. To say that FISA invalidly restricts the President's inherent powers reflects a conclusion that FISA violates the separation of powers doctrine..$^{51}$

I join other commentators in believing that analysis of this issue will be governed by Youngstown Sheet and Tube Co. v. Sawyer. ${ }^{52}$ In Youngstown, the Court invalidated President Truman's attempt to take over the nation's steel mills. Truman attempted the takeover to ensure that, despite labor unrest, the mills would continue to produce materiel for the Korean War. ${ }^{53}$ Truman argued that "his action was necessary to avert a national catastrophe which would inevitably result from a stoppage of steel production, and that in meeting this grave emergency [he] was acting within the aggregate of his constitutional powers as the Nation's Chief Executive and the commander in chief of the Armed Forces." 54 The Court rejected that argument. It held

${ }^{50}$ See supra notes ____ and accompanying text.

51 See, e.g., Attorney General Letter of Feb. 28, 2006, supra note _, at 5 ("[l]f an interpretation of FISA that allows the President to conduct the NSA activities were not fairly possible, and if FISA were read to impede the President's ability to undertake actions necessary to fulfill his constitutional obligation to protect the Nation from foreign attack in the context of a congressionally authorized armed conflict against an enemy that has already staged the most deadly foreign attack in our Nation's history, there would be serious doubt about the constitutionality of FISA as so applied."); McCarthy, supra note _, at 33-34 (similar argument).

${ }^{52} 343$ U.S. 579 (1952). See, e.g., ACLU v. NSA, 2006 WL 2371463, at *21-*24 (relying on Youngstown in analyzing NSA program); Nomination of Samuel A. Alito, Jr. to be an Associate Justice of the Supreme Court of the United States: Hearing Before the Sen. Comm. on the Judiciary, 109 ${ }^{\text {th }}$ Cong. - (Jan. 9, 2006) (testimony of Judge Samuel Alito) (stating that "I think one might look to Justice Jackson's framework" in Youngstown in addressing president's power to authorize NSA program); Senate Hearing of Feb. 6, 2006, supra note _, at _ (testimony of Attorney General Gonzales) ("[l]f Congress were to take some kind of action, and say the president no longer has the authority to engage in electronic surveillance of the enemy, then I think that would put us into the third part of Justice Jackson's three-part test" in Youngstown); ABA Task Force Report on NSA Surveillance, supra note _, at 13 (applying the "criteria set forth in Justice Jackson's famous concurring opinion in Youngstown" to analyze President's authorization of NSA program); Law Professors' Letter to Congress, supra note _ , at 15 (relying on Justice Jackson's "influential opinion" in Youngstown to analyze President's power to authorize the NSA program). But cf. McCarthy, supra note _, at 49-51 (Court's modern approach to separation of powers analysis is "more balanced and cautious" than Jackson's framework suggests when read in isolation).

${ }_{54}$ Youngstown, 343 U.S. at 585-89.

${ }^{54}$ Id. at 582. 
that Truman's action was not authorized by any statute or any extra-statutory power that the President has under the Constitution. ${ }^{55}$

The most authoritative opinion from Youngstown has come to be, not the majority's opinion, but Justice Jackson's concurrence. ${ }^{56}$ In his concurrence, Justice Jackson set out a three-part framework for analyzing the President's power. ${ }^{57}$ The framework reflects the interdependence of the President and Congress in certain matters, including war. ${ }^{58}$ Under the first part of the framework, the President's power is "at its maximum" when he or she acts with the express or implied authorization of Congress. ${ }^{59}$ In this first situation, the President has "all [of the power] that he [or she] possesses in his [or her] own right plus all that Congress can delegate."60 The second part of the framework applies when the President acts with neither congressional approval nor congressional denial of his or her authority. In this second situation, the President "can only rely upon his [or her] own independent powers." 61 The third part of the framework applies when the President takes action "incompatible with the expressed or implied will of Congress." ${ }^{62}$ In this third situation, the President's power "is at its lowest ebb, for then he [or she] can rely only upon his [or her] own constitutional powers minus any constitutional

\footnotetext{
${ }^{55}$ Id. at 585 ("The President's power, if any, ... must stem either from an act of Congress or from the Constitution itself."); id. at 585-88 (holding that executive order did not fall within any statute or constitutional power).

${ }^{56}$ Id. at 634-55 (Jackson, J., concurring); see, e.g., Dames \& Moore v. Regan, 453 U.S. 654, 662 (1981) (stating that, as parties in that case agreed, Justice Jackson's concurrence in Youngstown "brings together as much combination of analysis and common sense as there is in this area"); Patricia L. Bellia, Executive Power in Youngstown's Shadow, 19 CONST. COMMENT. 87, 89 n.11 (2002) (citing commentary recognizing influence of Jackson's concurrence); see also supra note _ (citing sources relying on Jackson's Youngstown framework to analyze President's power to authorize the current NSA surveillance program).

57 Youngstown, 343 U.S. at 635-38 (Jackson, J., concurring).

${ }^{58}$ Id. at 635 .

${ }^{59} / d$.

${ }^{60} / d$.

${ }^{61} / d$. at 637.

62 ld. at $637-38$.
} 
powers of Congress over the matter. Courts can sustain exclusive President control in such a case only by disabling Congress from acting upon the subject." ${ }^{63}$

Justice Jackson's framework makes it important to determine whether the NSA program is authorized by -- or is instead inconsistent with -- the express or implied will of Congress. The President argues that the NSA program is authorized by the AUMF, but this argument lacks merit. ${ }^{64}$ Without the AUMF to support it, electronic surveillance under the NSA program violates FISA and so presents Justice Jackson's third situation. Accordingly, the surveillance can fall within the President's power, despite violating FISA, only to the extent that Congress is constitutionally "disable[ed]" from curbing the President's power. ${ }^{65}$ The question becomes to what extent Congress can regulate the President's conduct of domestic electronic surveillance for national security purposes.

Precedent establishes that Congress has some regulatory power in this matter, but the precedent leaves the scope of that power unclear. The relevant precedent includes FISA itself, which was supported by Presidents Carter and Ford as a legitimate regulation of the President's power. ${ }^{66}$ Unfortunately, this legislative precedent has no direct analog in Supreme Court precedent. The Supreme Court has said that Congress can regulate electronic surveillance in the United States to investigate national security threats posed by domestic organizations. ${ }^{67}$ The Court has not addressed congressional regulation of surveillance of threats to national

\footnotetext{
${ }^{63}$ Id. at 637-38; see also Hamdan v. Rumsfeld, 126 S. Ct. 2749, 2774 n.23 (2006) ("Whether or not the President has independent power, absent congressional authorization, to convene military commissions, he may not disregard limitations that Congress has, in proper exercise of its own war powers, placed on his powers") (citing Jackson's concurrence in Youngstown, 343 U.S. at 637).

${ }^{64}$ See supra note _ and accompanying text.

${ }^{65}$ Youngstown, $34 \overline{3}$ U.S. at $637-38$.

${ }^{66} 50$ U.S.C. $\S 1805(a)(3)(A)$ (to issue order authorizing electronic surveillance, court must find that "the target of the electronic surveillance is a foreign power or an agent of a foreign power"); see also id. $\S$ 1801 (a) \& (b) (defining "foreign power" and "agent of a foreign power"); Seamon \& Gardner, supra note , at 336-37 (documenting support of Ford and Carter Administrations for FISA).

${ }^{67}$ United States v. U.S. Dist. Court (Keith), 407 U.S. 297, 324 (1972) (Keith) ("prior judicial approval is required for the type of domestic security surveillance involved in this case and ... such approval may be made in accordance with such reasonable standards as the Congress may prescribe").
} 
security posed by foreign agents and powers. ${ }^{68}$ Though not addressing that specific issue, the Court has recognized that Congress has significant power over foreign relations -- power that stems from, among other places, its power over foreign commerce. ${ }^{69}$ On the other hand, the Court has recognized that the President, too, has significant power over foreign affairs, including matters of foreign intelligence, that exists independently of Congress's power. ${ }^{70}$ Precedent does not establish to what extent the President's power is not only independent but also "plenary" -- meaning not reducible by Congress.

${ }^{68}$ See Senate Hearing of Feb. 28, 2006, at _ (testimony of Robert F. Turner) (stating that Keith case has been misunderstood as bearing on President's power to conduct surveillance of foreign threats to national security; Keith dealt only with "internal threats from domestic organizations"); id. at _ (stating that Keith "made no suggestion that Congress should put any constraints on foreign intelligence gathering"); see also Mitchell v. Forsyth, 472 U.S. 511, 533 (1985) (distinguishing surveillance of foreign threats to national security from surveillance of domestic threats to national security). Of course, although Keith does not address congressional regulation of surveillance of foreign threats to national security, nor does it cast doubt on Congress's power to regulate that subject.

${ }^{69}$ See Champion v. Ames, 188 U.S. 321, 351-52 (1903) ("the commerce with foreign countries ... which Congress $\mathrm{c}[\mathrm{an}]$ regulate ... includ[es] ... the transmission by telegraph of ideas, wishes, orders, and intelligence") (citing W. Union Tel. Co. v. Pendleton, 122 U.S. 347 (1887)). In addition to Congress's power to regulate the executive branch's gathering of foreign intelligence, Congress can regulate the federal courts' admission of evidence derived from that intelligence gathering, as Congress has done in FISA. See 50 U.S.C. $\S 1806$ (e) (authorizing motion to suppress evidence obtained in violation of FISA); see also Usery v. Tuner Elkhorn Mining Co., 428 U.S. 1, 31 (1976) (stating that Congress "has plenary power over the promulgation of evidentiary rules for the federal courts"). See generally Max Kidalov \& Richard H. Seamon, The Missing Pieces of the Debate Over Federal Property Rights Legislation, 27 HASTINGS CONST'L L.Q. 1, 60-61 (1999) (discussing Congress's power to make rules for the federal courts).

${ }^{70}$ See, e.g., United States v. Curtiss-Wright Export Corp., 299 U.S. 304, 319 (1936) (referring to "the very delicate, plenary and exclusive power of the President as the sole organ of the federal government in the field of international relations -- a power which does not require as a basis for its exercise an act of Congress"); see also Chicago \& Southern Air Lines v. Waterman S.S. Corp., 333 U.S. 103, 110 (1948) ("Congress may of course delegate very large grants of its power over foreign commerce to the President. The President also possesses in his [or her] own right certain powers conferred by the Constitution on him [or her] as Commander-in-Chief and as the Nation's organ in foreign affairs. [In those roles, he or she] has available intelligence services whose reports neither are nor ought to be published to the world."). In citing Curtiss-Wright, I do not mean to endorse its reasoning, which has received withering, cogent criticism. Charles A. Lofgren, United States v. Curtiss-Wright Export Corporation: An Historical Reassessment, 83 YALE L.J. 1, 32 (1973) (concluding that "major segments" of Curtiss-Wright rest on history that is "shockingly inaccurate"); David M. Levitan, The Foreign Relations Power: An Analysis of Mr. Justice Sutherland's Theory, 55 YALE L.J. 467, 496 (1946) (finding "little room" for acceptance of Curtiss-Wright's concept of President's inherent extra-constitutional powers in "political and constitutional ideas" prevailing at time of American Revolution and framing of Constitution). I am arguing that the President has some margin to act contrary to law, provided it is not very long and he or she gets statutory authority as quickly as possible. In Curtiss-Wright, Sutherland saw no need for statutory authority. The President had exclusive, independent, inherent, and extraconstitutional powers, not dependent at all on congressional support. See E-mail from Louis Fisher, supra note 
Though not providing clear guidance, history and precedent suggest that the President has congressionally irreducible power to "repel sudden attacks" on the country. ${ }^{71}$ In The Prize Cases, for example, the Court upheld the President Lincoln's power to blockade southern ports in the days after the Confederacy's attack on union forces at Fort Sumter. ${ }^{72}$ The Court made clear this power did not depend on legislative authorization, stating: "If a war be made by invasion of a foreign nation, the President is not only authorized but bound to resist force by force. He does not initiate the war, but is bound to accept the challenge without waiting for any special legislative authority. ... He must determine what degree of force the crisis demands." ${ }^{73}$ Significantly, The Prize Cases was a 5-to-4 decision, with the four dissenters concluding that, because Congress had not declared war, "the President had no power to set on foot a blockade." ${ }^{74}$ The Court's decision, in substance and voting alignment, implies at most a narrow power in the President to take defensive measures in response to attacks on the country -- and

\footnotetext{
${ }^{71}$ See, e.g., Committee on International Security Affairs of the Ass'n of the Bar of the City of New York, The Legality and Constitutionality of the President's Authority to Initiate an Invasion of Iraq, 41 Colum. J. Transnat'I L. 15, 19 n.13 (2002) ("Messrs. Madison and Gerry jointly introduced the amendment to substitute 'declare' for 'make' [in the clause enumerating Congress's war power]. They noted the change would 'leav[e] to the Executive the power to repel sudden attacks.' M. Farrand, The Records of the Federal Convention of 1787 (rev. ed. 1937), at 318, cited in The Constitution of the United States of America: Analysis and Interpretation, Congressional Research Service (1992), at 308, note 1420."); see also War Powers Resolution, Pub. L. No. 93-148, § 2(c), 87 Stat. 555 (1973), (codified at 50 U.S.C. § 1541(c)) ("The constitutional powers of the President as Commander-in-Chief to introduce United States Armed Forces into hostilities, or into situations where imminent involvement in hostilities is clearly indicated by the circumstances are exercised pursuant to [in addition to congressional authorization] ... (3) a national emergency created by attack upon the United States, it territories or possessions, or its armed forces"); Jane E. Stromseth, Understanding Constitutional War Powers Today: Why Methodology Matters, 106 YALE L.J. 845, 852-63 (1996) (reviewing LOUIS FISHER, PRESIDENTIAL WAR POWER (1995)) (describing range of scholarly views on President's war powers, including power to repel imminent attacks on the country). Presidential power expert Louis Fisher traces the claim of presidential power to act contrary to law in cases of genuine emergency to the Lockean Prerogative. See LOUIS FISHER, Constitutional Conflicts BetWeEn Congress AND tHe President 259-260 (rev. $4^{\text {th }}$ ed. 1997). Until recently, Presidents exercised the power but later sought authorization from Congress. Id. at 260-62. ${ }^{72}$ The Amy Warwick ("The Prize Cases"), 67 U.S. 635 (1862).

${ }^{73}$ Id. at 670 .

${ }^{74}$ Id. at 698 (Nelson, J., dissenting, joined by Taney, C.J., and Catron and Clifford, JJ.); see also Holmes v. United States, 391 U.S. 936, 946-947 (1968) (Douglas, J., dissenting) (discussing The Prize Cases).
} 
one that may exist in the absence of "special legislative authority" but that does not necessarily exist when it contradicts legislative authority. ${ }^{75}$

More recently, two Justices in Hamdi v. Rumsfeld recognized a similar, but broader, emergency power to respond to threats to national security. ${ }^{76}$ In Hamdi, Justice Souter (joined by Justice Ginsburg) dissented from a decision upholding the detention of an asserted enemy combatant who is also a U.S. citizen. ${ }^{77}$ Justice Souter concluded that an Act of Congress barred the detention. ${ }^{78}$ He suggested, however, that the executive branch might be able to detain a citizen, even in violation of the statute, "in a moment of genuine emergency, when the Government must act with no time for deliberation."79 The plurality did not address this issue because it held -- contrary to Justice Souter's dissent (but in basic agreement with Justice Thomas's dissent) -- that the detention in that case was authorized by federal statute. ${ }^{80}$ The

${ }^{75}$ See also Halperin v. Kissinger, 606 F.2d 1192, 1201 (D.C. Cir. 1979) ("[W]hatever special powers the Executive may hold in national security situations must be limited to instances of immediate and grave peril to the nation. Absent such exigent circumstances, there can be no appeal to powers beyond those enumerated in the Constitution or provided by law."); cf. Little v. Barreme, 6 U.S. 170, 177-79 (1804) (captain of U.S. vessel was personally liable in damages for seizing a vessel in violation of statute, even though the seizure comported with presidential orders, because presidential orders misconstrued the statute). As Dr. Louis Fisher observed in commenting on a draft of this article, the Prize Cases may also be distinguishable from what is called the "global war on terrorism," of which the current NSA surveillance program is part, because President Lincoln acted in a domestic context, rather than in a context in which he was taking the country from a state of peace to a state of war with another nation. See E-mail from Louis Fisher, supra note _ (citing Prize Cases, 67 U.S. at 660 (argument of counsel for government, distinguishing foreign war from civil war)).

${ }^{76} 542$ U.S. 507 (2004); see also Joseph R. Biden, Jr, \& John B. Ritch III, The War Power at a Constitutional Impasse: A 'Joint Decision' Solution, 77 GEO. L.J. 367, 372 (1988) (proposing a "joint decision" model under which presidential power to use force in absence of statutory authorization "derives from the concept of emergency: the need to repel an attack on the United States or its forces, to forestall an imminent attack, or to rescue United States citizens whose lives are imperiled").

${ }^{77}$ Hamdi, 542 U.S. at 539-54 (Souter, J., concurring in part, dissenting in part, and concurring in the judgment, joined by Ginsburg, J.).

78 Id. at 541.

${ }^{79}$ Id. at 552.

${ }^{80} \mathrm{Id}$. at 517 (O'Connor, J., announcing judgment of the Court and delivering an opinion in which Rehnquist, C.J., Kennedy and Breyer, JJ., joined) (holding that "Congress has in fact authorized Hamdi's detention"); id. at 579-94 (Thomas, J., dissenting) (finding that President's detention of Hamdi fell within "powers vested in the President by the Constitution and with explicit congressional approval"). Justice Thomas believed that the plurality understood the President's power under the Constitution and the AUMF too narrowly. See id. at 587-93. Justice Thomas also disagreed with the Court's disposition, which remanded the case for Hamdi to have "a meaningful opportunity to contest the factual basis for [his] detention" (id. at 509 (opinion of O'Connor, J., announcing judgment of the Court); id. at 553 (Souter, J., joined by Ginsburg, J., concurring in remand)). See id. at 579 (Thomas, J., dissenting) (concluding that "there is no reason to remand the case" because Hamdi's habeas challenge should fail). 
Hamdi dissent implies that the President's power to take action "incompatible with the expressed or implied will of Congress" (the third situation identified by Justice Jackson's Youngstown concurrence) may include the power to take immediate action to respond to a "genuine emergency" threatening national security. ${ }^{81}$ Furthermore, the Hamdi dissent did not limit its implication of presidential power to situations involving an actual attack. Indeed, even before Hamdi many commentators believed that the President's power encompasses taking defensive measures necessary to thwart imminent attacks. ${ }^{82}$

Initially, the Court's recent decision in Hamdan v. Rumsfeld might be read to cast doubt on the existence of any plenary power in the President to defy an Act of Congress when he believes it necessary to respond to a national security threat. ${ }^{83}$ In Hamdan, the Court held that the President violated an Act of Congress -- namely, the Uniform Code of Military Justice (UCMJ) -- when he established military tribunals to try aliens detained in the war on terrorism. ${ }^{84}$ The Court held that the President's order establishing the tribunals violated two UCMJ

${ }^{81}$ Youngstown, 343 U.S. at 635-38 (Jackson, J., concurring).

${ }^{82}$ See Biden \& Ritch, supra note _, at 398-99 (proposing legislation that authorizes the President, without additional statutory authority, to take various actions including "to forestall an imminent act of international terrorism known to be directed at citizens or nationals of the United States"); Stromseth, supra note _, at 862-863 (expressing the view that President has power without congressional consent to respond not only to actual attacks but also to "imminent attacks" and to "exercise the nation's fundamental right of self-defense when a foreign force "by its own actions placed the United States in a state of war"); Jane E. Stromseth, Collective Force and Constitutional Responsibility: War Powers in the Post-Cold War Era, 50 U. MIAMI L. REV. 145, 159 (1995) ("In exceptional cases, the President may determine that aggression short of an attack or imminent attack against the United States poses a threat to the country's security that is serious enough to warrant dispatching American forces into combat within a time frame that precludes prior approval from Congress."); William Van Alstyne, Congress, the President, and the Power to Declare War: A Requiem for Vietnam, 121 U. PA. L. REV. 1, 9 (1972) ("[T]he lodgment of the power to declare war exclusively in Congress forbids the sustained use of armed force abroad in the absence of a prior, affirmative, explicit authorization by Congress, subject to the one emergency exception: an interim emergency defense power in the President to employ armed force to resist invasion or to repel a sudden armed attack until Congress can be properly convened to deliberate on the question as to whether it will sustain or expand the effort by specific declaration or, by doing nothing, require the President to disengage our forces from the theater of action."); cf. Martin v. Mott, 25 U.S. 19, 29 (1827) (stating of Congress's power that "the power to provide for repelling invasions includes the power to provide against the attempt and danger of invasion, as the necessary and proper means to effectuate the object").

83126 S. Ct. 2749 (2006).

${ }^{84}$ Id. at 2790-98. 
provisions. First, the President's order violated Article 36 of the UCMJ. ${ }^{85}$ Article 36, as the Court interpreted it, requires rules the rules for military tribunals to be the same as the rules for courts martial to the extent practicable. ${ }^{86}$ Although the President had determined that it would be impracticable to have the military tribunals operate under the same rules as do courts martial, the Court found that determination "insufficient." ${ }^{87}$ Second, the Court found that the President's rules for military tribunals violated UCMJ Article 21. Article 21 requires the rules for military tribunals to comply with "the law of war." 88 The Court determined that the tribunals' rules violated the Geneva Conventions, which the government conceded are part of "the law of war." ${ }^{89}$ In short, the Court invalidated the President's rules because they conflicted with an Act of Congress.

Some early commentators believe that Hamdan casts serious doubt on the legality of the NSA surveillance program because that program, like the President's rules for tribunals, violates an Act of Congress: namely, the FISA. ${ }^{90}$ The provisions of the UCMJ at issue in Hamdan, however, unlike the FISA provisions with which the NSA surveillance program conflicts, were not challenged by the government as unconstitutionally infringing on the President's inherent powers. As Justice Thomas noted in his Hamdan dissent, the Court did not need to decide the President has inherent authority to use military tribunals to try suspected terrorists. ${ }^{91}$ The issue before the Court was whether the President's action fell within "certain statutes, duly enacted by

${ }_{86}^{85}$. at 2790 (discussing Art. 36 of UCMJ, 10 U.S.C. $\S 836$ ).

${ }^{86}$ Id. at $2790-93$.

${ }^{87}$ Id. at 2791.

${ }^{88} / d$. at 2794 (discussing Article 21 of the UCMJ, 10 U.S.C. § 821).

${ }^{89} / d$. at 2794.

90 See Editorial, Who Watches Those Who Watch Us?, Nw. Fla. (ForT WaLton BEAch) Daily NeWs, July 26, 2006, (quoting interview in which Marc Rotenberg, Executive Director of Electronic Privacy Information Center, states that Hamdan "told the executive branch that it doesn't have unlimited power under the Constitution to do whatever it thinks is necessary, even in times of war," and arguing that the decision dampens congressional enthusiasm for legislation authorizing NSA surveillance program); Letter from Jerrold Nadler, Member of U.S. House of Representatives, to Alberto Gonzales, U.S. Attorney General (July 26, 2006) (stating that Court's decision in Hamdan makes it untenable for President to rely on inherent powers to justify NSA surveillance program), available at 7/26/06 USFEDNEWS (Westlaw).

${ }^{91}$ Id. at 2825 n.2 (Thomas, J., dissenting). 
Congress ... in the proper exercise of its powers as an independent branch of government." 92 Perhaps the government did not challenge the UCMJ provisions at issue in Hamdan because they leave room for the President to act as necessary in genuine national security emergencies. UCMJ Article 36 authorizes the President, when establishing military tribunals, to depart from the rules for courts martial if it is "impracticable" to use identical rules. ${ }^{93}$ UCMJ Article 21 obligates the President to follow the "laws of war" in the use of military tribunals, but the laws of war, in turn, authorize the use of military tribunals "in cases of 'controlling necessity.'"94 Thus, both statutory provisions arguably reflect that as necessary in exigent circumstances the President has authority to depart from their otherwise applicable strictures.

Recognizing a congressionally irreducible "genuine emergency" power in the President is supported by the Constitution's creation of a "unitary executive." ${ }^{95}$ The Constitution provided for only one president so, in appropriate occasions, someone can act for the nation without consulting others. ${ }^{96}$ The Framers thought a unitary executive was particularly important for conducting foreign affairs. A unitary executive not only enables the country to speak to other countries with one voice. ${ }^{97}$ It also ensures quick action when necessary to protect national security. ${ }^{98}$ Too, it helps ensure the secrecy of sensitive foreign intelligence. ${ }^{99}$ Thus, the Court

\footnotetext{
92 Id. at 2799 (Kennedy, J., concurring in part).

9310 U.S.C. $\S 836$.

${ }^{94}$ See Hamdan, 126 S. Ct. at 2774 (quoting Ex parte Milligan, 71 U.S. 2, 139-40 (1866), and explaining that the law of war, as described in Milligan, was initially codified in UCMJ Article 15 and later in UCMJ Article 21); see also Hamdan, 126 S. Ct. at 2785 (opinion of Stevens, J.) (referring to the "inability on the Executive's part here to satisfy the most basic precondition -- at least in the absence of specific congressional authorization -- for establishment of military commissions: military necessity"). ${ }^{95}$ See, e.g., Clinton v. Jones, 520 U.S. 681, 712-13 (1997) (Breyer, J., concurring in the judgment) (discussing unitary executive); THE FEDERALIST No. 70, at 452 (Alexander Hamilton) (Benjamin Fletcher Wright ed. 1961) ("Decision, activity, secrecy, and d[i]spatch will generally characterize the proceedings of one man in a much more eminent degree than the proceedings of any greater number."); Christopher S. Yoo, Steven G. Calabresi \& Anthony J. Colangelo, The Unitary Executive in the Modern Era, 19452004, 90 IOWA L. REV. 601 (2005).

${ }^{96}$ See 10 ANNALS CONG. 613 (1800) (argument of John Marshall that "the President is the sole organ of the nation in its external relations, and its sole representative with foreign nations").

${ }^{97}$ Curtiss-Wright, 299 U.S. at 220 ("The President is the constitutional representative of the United States with regard to foreign nations.") (quoting 8 U.S. Senate Reports Comm. On Foreign Relations 24 (Feb. 15, 1816).

${ }^{98}$ See THE Federalist No. 70, supra note _ , at 451-52 ("Energy in the executive ... is essential to the protection of the community against foreign attacks," and an ingredient of energy is "unity"); see also
} 
has often referred to the President as the "sole organ" of foreign affairs. ${ }^{100}$ The "sole organ" concept cannot, however, be stretched so far that it puts the President indefinitely above the law. Rather, it makes sense to let the President act as the "sole organ" if -- but only so long as - it is necessary in a genuine national security emergency for him or her to so function. ${ }^{101}$

This conclusion leaves many questions unanswered. They include the questions of who decides whether a national security emergency exists and what response is appropriate. ${ }^{102}$ As a practical matter, the President initially must decide those questions. ${ }^{103}$ Courts, however, can often review those decisions when they are implemented by officials other than the President

LOUIS FISHER, PRESIDENTIAL WAR POWER 6 (1995) (explaining that Framers believed President should have power to repel foreign attacks without congressional approval partly because Congress was expected to meet only about once a year).

${ }^{99}$ See Chi. \& S. Air Lines, Inc. v. Waterman S.S. Corp., 333 U.S. 103, 111 (1948) ("The President, both as Commander-in-Chief and as the Nation's organ for foreign affairs, has available intelligence services whose reports are not and ought not to be published to the world."); Curtiss-Wright, 299 U.S. at 320 ("Secrecy in respect of information gathered by [President's "confidential sources of information"] may be highly necessary [in the "field of international relations"] and the premature disclosure of it productive of harmful results"); EdWARD S. CORWIN, THE PRESIDENT: OfFICE AND POWERS 5-7, 200-01 (Randall W. Bland et al. eds. $5^{\text {th }}$ ed. 1984) (citing among President's advantages over Congress in the conduct of foreign policy the unitary nature of the Presidency, its ability to collect and maintain secrecy of relevant information, and to act quickly); see also THE FEDERALIST No. 64 (John Jay), supra note _, at 422 (many who provide useful intelligence related to treaties "would rely on the secrecy of the President" but not on that of the Senate or House of Representatives, and therefore Constitution's framers wisely provide that President "will be able to manage the business of intelligence in such a manner as prudence may suggest") (quoted in Robert F. Turner, Op-Ed, FISA vs. the Constitution, WALL ST. J., Dec. 28, 2005, at A14.

100 Pasquantino v. United States, 544 U.S. 349, 369 (2005) ("In our system of government, the Executive is 'the sole organ of the federal government in the field of international relations... ."') (quoting CurtissWright, 299 U.S. at 320); see also Am. Ins. Ass'n v. Garamendi, 539 U.S. 396, 414 (2003) ("[T]he historical gloss on the 'executive Power' vested in Article II of the constitution has recognized the president's 'vast share of responsibility for the conduct of our foreign relations."') (quoting Youngstown, 343 U.S. at 610-11 (1952)); Sale v. Haitian Ctrs. Council, Inc., 509 U.S. 155, 188, 113 S. Ct. 2549, 125 L.Ed.2d 128 (1993) (President has "unique responsibility" for the conduct of "foreign and military affairs"); First Nat'I City Bank v. Banco Nacional de Cuba, 406 U.S. 759, 769 (1972) (plurality opinion) (President has "the lead role ... in foreign policy").

${ }^{101}$ Cf. Michael Stokes Paulsen, The Constitution of Necessity, 79 NOTRE DAME L. REV. 1257, 1257-58 (2004) (arguing for recognition of a constitutional principle of necessity that can even "trump specific constitutional requirements" if necessary to "national self-preservation").

${ }^{102}$ Cf. Paulsen, supra note _, at 1289-96 (discussing standard and identity of decision maker for proposed constitutional principle of necessity).

${ }_{103}$ See Martin, 25 U.S. at 31 (in determining whether to call up the state militia pursuant to statutory and constitutional authority, the President "is necessarily constituted the judge of the existence of the exigency in the first instance, and is bound to act according to his belief of the facts"). 
and affect individual rights. ${ }^{104}$ Indeed, sometimes the federal courts can set aside such decisions, as the Court's recent decision in Hamdan v. Rumsfeld shows. ${ }^{105}$ Thus, regardless of the power the President may individually possess as a "unitary executive," he is judicially accountable in many settings. In addition to being judicially accountable, the President is politically accountable for his or her unilateral responses to genuine national security emergencies, at least once those decisions become public. ${ }^{106}$

By any standard, 9/11 constituted a genuine national security emergency. ${ }^{107}$ It accordingly empowered the President to take some immediate actions that he reasonably thought necessary, even if those actions violated federal statutes. Suppose, for example, that the passengers aboard United Airlines Flight 93 had not caused the plane to crash in Shanksville, Pennsylvania, and that it had continued its suicide mission toward the U.S. Capitol. ${ }^{108}$ Can anyone doubt that the President could have ordered the flight shot down before it hit the Capitol, even if that order violated a federal statute ${ }^{109}$ Similarly, suppose the President had ordered the instant electronic monitoring of all cell phone calls to and from the

${ }^{104}$ See Youngstown, 343 U.S. at 591 (Court reviewed Executive Order that recited existence of an "emergency" that required takeover of the nation's steel mills); see also Alderman v. United States, 394 U.S. 165, 176-85 (1969) (prescribing standards and procedures by which criminal defendant could identify and seek suppression of evidence gathered through electronic surveillance for national security purposes); cf. Martin, 25 U.S. at 32-33 (rejecting the argument that court could try the facts underlying President's determination that emergency existed justifying the call up of the militia); Marbury v. Madison, 5 U.S. 137, 169-172 (1803) (concluding that mandamus would lie to order head of federal government department to take action compelled by law, where failure to take the action injured individual's vested legal rights).

105126 S. Ct. 2749 (2006)

106 See Martin, 25 U.S. at 32 (danger of President's abusing statutory and constitutional authority to call up the militia in times of emergency lay in "the frequency of elections, and the watchfulness of the representatives of the nation," which "carry with them all the checks which can be useful to guard against usurpation or wanton tyranny").

${ }^{107}$ See Declaration of National Emergency by Reason of Certain Terrorist Attacks, 66 Fed Reg. 48,199 (Sept. 14, 2001) (presidential declaration of emergency).

108 See The 9/11 Commission Report: Final RePORT OF THE NATIONAL COMmission ON TERRORISt AtTACKS UPON THE UNITED STATES 10-14 (2004) (describing events leading to the crash of United Airlines Flight 93).

${ }^{109}$ See 9/11 COMmISSION REPORT, supra note __, at 37, 45 (discussing contingent "shootdown order" issued for Flight 93). 
plane to determine the plane's target and those responsible for the suicide mission. Would not the President have authority to order that surveillance even if it violated FISA? ${ }^{110}$

One basis for concluding that the President would have that authority is to interpret FISA (and other statutes limiting the President's power in genuine emergencies) implicitly to include exceptions for genuine emergencies. That interpretation finds support in the canon requiring courts to avoid statutory interpretations that produce "absurd results." ${ }^{111}$ But the canon should not obscure the reason why it would be absurd to interpret FISA to prohibit the President from responding to genuine national security emergencies: It is absurd to give Congress such a prohibitory power. To the contrary, common sense and precedent support recognition of presidential power, irreducible by Congress, to make necessary, immediate responses to genuine national security emergencies.

Of course, the President's "genuine emergency" power has limits. The Japanese attack on Pearl Harbor created a "genuine emergency," but that emergency did not last for the entire war. ${ }^{112}$ Nor did the attack on Pearl Harbor necessarily justify every measure that the President deemed reasonable, including the mass internment of Japanese Americans. ${ }^{113}$ The existence

\footnotetext{
${ }^{110}$ Cf. Senate Hearing of Feb. 28, 2006, supra note _, at _ (testimony of former CIA Director James Woolsey) (stating that President's "inherent authority" justifies NSA surveillance program "because the country has been invaded -- albeit, of course, not occupied -- and defending against invasion was at the heart of the president's Article 2 authority for the founders").

${ }^{111}$ See, e.g., Clinton, 524 U.S. at 429. Supporting the interpretation described in the text is a statement by then-Attorney General Griffin Bell that the bill enacted as FISA "does not take away the power [of] the President under the Constitution." Foreign Intelligence Electronic Surveillance Act of 1978: Hearings on H.R.5764, H.R. 9745, H.R. 7308, and H.R. 5632 Before the Subcomm. on Legislation of the House Comm. on Intelligence, 95th Cong. 15 (1978).

112 See Ex parte Milligan, 71 U.S. 2, 80 (1866) ("As necessity creates the rule [allowing military tribunals to serve the function of civil courts when the latter are closed due to foreign invasion or civil war], so it limits its duration."); id. at 127 (martial law justified only by "actual and present" necessity as in a genuine invasion that closes civilian courts); see also Hirabayashi v. United States, 320 U.S. 81, 113 (1943) (Murphy, J., concurring) ("[T]he military arm, confronted with the peril of imminent enemy attack and acting under the authority conferred by Congress, made an allowable judgment at the time the curfew restriction [upon Japanese Americans living in certain areas of the West Coast] was imposed. Whether such a restriction is valid today is another matter.").

${ }^{113}$ See Hirabayashi, 320 U.S. at 102 (upholding executive order, ratified by Congress, imposing curfew on Japanese Americans in certain areas during World War II, while emphasizing that other wartime measures affecting Japanese Americans (such as internment) were not before the Court); see also Korematsu v. United States, 323 U.S. 214, 217-18 (1945) (upholding Executive Order excluding Japanese Americans from certain areas).
} 
of genuine emergency powers in the President -- and the relaxation of Bill-of-Rights limits on those powers -- must be limited in time and scope. ${ }^{114}$ Otherwise, the separation of powers system cannot work effectively and Bill of Rights freedoms become fair weather friends. I propose two limits on the President's "genuine emergency" powers.

First, the President's power depends on the legislative framework within which it is exercised. The President can defy an Act of Congress in a national security emergency only if defiance of the legislation is necessary to respond to the emergency. If the President can effectively respond to the emergency while obeying the statute, the President lacks power to defy it. ${ }^{115}$ Thus, Congress can regulate the President's power to respond to national security emergencies by enacting legislation that gives the President adequate leeway in such emergencies. By the same token, it is the inadequacy of legislation that justifies presidential defiance of the legislation in cases of genuine emergency. ${ }^{116}$

Second, the President's emergency powers are residual when Congress has enacted generally valid legislation in the same area. Congress and the President share power in many

${ }^{114}$ Cf. Korematsu v. United States, 323 U.S. 214, 234 (1944) (Murphy, J., dissenting) ("The judicial test of whether the Government, on a plea of military necessity, can validly deprive an individual of any of his constitutional rights is whether the deprivation is reasonably related to a public danger that is so 'immediate, imminent, and impending' as not to admit of delay and not to permit the intervention of ordinary constitutional processes to alleviate the danger.").

115 The President has claimed that the NSA surveillance program is "crucial to our national security." Letter from William E. Moschella, Assistant Attorney General, Office of Legislative Affairs, U.S. Dep't of Justice, to Sen. Pat Roberts et al. 1 (Dec. 22, 2005) ("The President has stated that these activities are 'crucial to our national security.'"), available at http://www.fas.org/irp/agency/doj/fisa/doj122205.pdf. The President has not (publicly, at least) shown why it is necessary to ignore FISA in conducting that program.

${ }_{116}$ See Foreign Intelligence Surveillance Act: Hearings Before the Subcomm. on Courts, Civil Liberties, and the Administration of Justice of the House Comm. on the Judiciary, $94^{\text {th }}$ Cong. 92 (1976) (testimony of Attorney General Edward H. Levi) ("[]W]hen a statute prescribes a method of domestic [surveillance] action adequate to the President's duty to protect the national security, the President is legally obliged to follow it.") (emphasis added); see also Senate Hearing of Mar. 28, 2006, supra note _, at _ (prepared statement of David S. Kris, Senior Vice President, Time Warner, Inc.) (separation of powers analysis of NSA program will depend partly on "the [executive branch's] need to eschew the use of FISA in obtaining" needed information); cf. Chambers v. NASCO, Inc., 501 U.S. 32, 58 \& 60 (1991) (Scalia, J., dissenting) (stating that federal courts have inherent and congressionally "indefeasible" power to "do what courts have traditionally done in order to accomplish their assigned tasks," and, while Congress "may to some degree" prescribe the means for exercising that power, courts can ignore the prescribed congressionally prescribed means if those means are inadequate); id. at 65 (Kennedy, J., dissenting) (positing a similar "necessity limitation" on federal courts' exercise of congressionally irreducible inherent powers). 
areas, including the waging of war. ${ }^{117}$ In matters of shared governance, the separation of powers doctrine gives Congress the power to make rules and the President power -- not to unmake Congress's rules -- but to break them when reasonably necessary in a genuine emergency. For example, in late 2005 Congress enacted a law prohibiting members of the armed forces from torturing people detained in the war on terrorism. ${ }^{118}$ Assume for the sake of argument that it is possible to conceive of a "genuine emergency" in which the President could reasonably decide it was necessary to defy this prohibition. ${ }^{119}$ It is one thing to recognize presidential power to break Congress's rule in a particularly exigent situation, after making an individualized determination that it was necessary to violate the prohibition. It is quite a different matter to recognize presidential power to unmake Congress's rule by promulgating a "program" authorizing torture in broadly defined categories of situations. ${ }^{120}$ One way to express the difference is by saying that, in the second situation, the President is impermissibly exercising legislative power, whereas in the first situation he is exercising irreducible executive power. ${ }^{121}$

117 Hamdan, 126 S. Ct. at 2773 (discussing Constitution's grants of war powers to President and Congress); Hirabayashi, 320 U.S. at 93 ("[T]he Constitution commits to the Executive and to Congress the exercise of the war power... ."); see also, e.g., Rumsfeld v. Forum for Academic \& Inst'l Rights, $126 \mathrm{~S}$. Ct. 1297, 1306 (2006) (("'[J]udicial deference ... is at its apogee' when Congress legislates under its authority to raise and support armies.") (quoting Rostker v. Goldberg, 453 U.S. 57, 70 (1981)).

${ }_{118}$ Detainee Treatment Act of 2005, Pub. L. No. 109-148, § 1003, 119 Stat. 2680, 2739 (Dec. 30, 2005) ("No individual in the custody or under the physical control of the United States Government, regardless of nationality or physical location, shall be subject to cruel, inhuman, or degrading treatment or punishment.").

${ }^{119}$ To be clear, I am indeed staking out the position that the President has power to ignore anti-torture legislation when reasonably necessary to respond to a genuine national security emergency. Although the President's power in this regard is not congressionally irreducible, it is, of course, subject to constitutional restrictions, such as those imposed by the Fourth, Fifth, and Eighth Amendments. See Richard H. Seamon, U.S. Torture as a Tort, 37 RUTGERS L.J.___ (forthcoming summer 2006) (discussing constitutional limits on government's power to torture suspected terrorists); see also Paulsen, supra note , at 1280 (taking a similar position). Furthermore, even if Congress lacks power to prohibit executive branch torture in certain situations, Congress might have power to exclude evidence derived from that torture in federal courts. See, e.g., United States v. Williams, 504 U.S. 36, 55 (1992) (stating in dicta that Congress could require disclosure to criminal defendants of exculpatory evidence presented to the grand jury, even if Constitution did not require disclosure).

${ }_{120}$ See Youngstown, 343 U.S. at 587 ("[T]he President's power to see that the laws are faithfully executed refutes the idea that he is to be a lawmaker.").

${ }^{121}$ The President's power in the legislative process, as specifically prescribed in the Constitution, includes recommending legislation to Congress. Certainly the President could have done so in the 4 year since first authorizing the NSA program. See Dan Eggen, 2003 Draft Legislation Covered Eavesdropping, Wash. Post, Jan. 28, 2006, at A2 (observing that Department of Justice drafted legislation in 2003 to 
Another way to express the difference is to say that the executive power to act in "emergencies"

is limited in scope and duration to that necessary when there is "no time for deliberation." 122

Those limits flow from our system of separated powers.

\section{B. Fourth Amendment Constraints on Presidential Powers in a "Genuine Emergency"}

The hypothetical surveillance order described above, covering all cell phone calls to and

from the doomed Flight 93, falls not only within the intrinsic limits of the President's powers

under Article II but also within the extrinsic limits imposed by the Fourth Amendment. ${ }^{123}$

Ordinarily, the Fourth Amendment requires the government to get a warrant before

electronically intercepting phone calls. ${ }^{124}$ In addition, the Fourth Amendment ordinarily requires

a particularized showing that the monitoring of each phone user is likely to reveal evidence of

amend Patriot Act but, according to Justice Department officials, the draft legislation did not address the NSA program).

122 Hamdi, 542 U.S. at 552; see also Transcript of Oral Argument at 28-29, Hamdi, 542 U.S. 507 (No. $03-$ 6696) (Justice Souter remarks, "[l]t may well be that the executive has power in the early exigencies of an emergency. But that at some point in the indefinite future, the other political branch has got to act if that ... power is to continue."); JOHN HART ELY, WAR AND RESPONSIBILITY: CONSTITUTIONAL LESSONS OF VIETNAM AND ITS AFTERMATH 5-9 (1993) (proposing that, in response to sudden attack, President can respond without congressional authorization if he seeks such authorization simultaneously); William C. Bradford, "The Duty to Defend Them: A Natural Law Justification for the Bush Doctrine of Preventive War, 79 NOTRE DAME L. REV. 1365, 1448 (2004) ("[l]n the event of an invasion or other imminent harm against U.S. citizens or property, inherent presidential powers of self-defense -- for the exercise of which the President need neither seek nor receive congressional authorization -- are triggered, even if the President remains obligated to make a subsequent request for congressional authorization for his course of action.") (footnote omitted); John W. Dean, George W. Bush as the New Richard M. Nixon: Both Wiretapped Illegally, and Impeachably; Both Claimed That a President May Violate Congress' Laws to Protect National Security, FindLaw (Dec. 30, 2005) (stating that NSA surveillance program might have been justified "as a temporary measure" or in response to "a particularly serious threat of attack," but program is not justified considering all of the time that President has had, and not used, "to seek legal authority for his action" from Congress), http://writ.news. findlaw.com/dean/20051230.html; cf. Mitchell v. Harmony, 54 U.S. 115134 (1851) (for military to have power to take private property for military use, "the danger must be immediate and impending; or the necessity urgent for the public service, such as will not admit of delay, and where the action of the civil authority would be too late in providing the means which the occasion calls for").

${ }^{123}$ See generally, e.g., David E. Engdahl, Intrinsic Limits of Congress' Power Regarding the Judicial Branch, 1999 BYU L. REV. 75, 79 ("Intrinsic limits derive from the principle of enumerated powers."); id. at 153 (describing Bill of Rights as containing "extrinsic limits").

${ }^{124}$ United States v. White, 401 U.S. 745, 758 (1971) ("We held in Berger v. New York, 388 U.S. 41 ... [(1967)] that wiretapping is a search and seizure within the meaning of the Fourth Amendment and therefore must meet its requirements, viz., there must be a prior showing of probable cause, the warrant authorizing the wiretap must particularly describe the place to be searched, and the persons or things to be seized, and that it may not have the breadth, generality, and long life of the general warrant against which the Fourth Amendment was aimed.") (internal quotation marks omitted). 
crime. $^{125}$ The traditional Fourth Amendment requirements of a warrant and an individualized showing of probable cause for a search do not, however, apply to our Flight 93 scenario. The exigent circumstances doctrine of Fourth Amendment law justifies immediate, warrantless surveillance of all cell phone users on board the flight. ${ }^{126}$ Moreover, although the exigent circumstances doctrine normally requires a particularized showing of probable cause of criminal activity, ${ }^{127}$ that showing is unnecessary when "special needs, beyond the normal need for law enforcement," makes the probable cause requirement impracticable. ${ }^{128}$ The Flight 93 scenario

\footnotetext{
${ }^{125}$ See id.

${ }^{126}$ See, e.g., Warden v. Hayden, 387 U.S. 294, 298 (1967) (holding that police's warrantless entry into home and search for bank robber did not violate the Fourth Amendment because "the exigencies of the situation made that course imperative") (internal quotation marks omitted); see also Georgia v. Randolph, 126 S. Ct. 1515, 1524 n.6 (2006) (stating in dicta that exigent circumstances would justify police's entry into a house, over the objection of a co-tenant, when necessary to preserve evidence or in other circumstances); Zweibon v. Mitchell, 516 F.2d 594, 649-50 (D.C. Cir. 1975) (en banc) (plurality opinion of Wright, J., joined by Chief Judges Bazelon and Circuit Judges Leventhal and Spottswood W. Robinson, III) (finding that exigent circumstances doctrine would allow warrantless electronic surveillance when delay would cause "disastrous harm to the national security")

${ }^{127}$ See, e.g., Hayden, 387 U.S. at 307.

128 See Griffin v. Wisconsin, 483 U.S. 868, 873 (1987) (quoting New Jersey v. T.L.O., 469 U.S. 325, 351
} (1985) (Blackmun, J., concurring in judgment)). As the text indicates, the exigent circumstances doctrine and the "special needs" doctrine sometimes overlap. The overlap occurs when exigent circumstances, such as those associated with national security emergencies, trigger a "special need" for searches and seizures beyond that associated with ordinary law enforcement. Two recent Supreme Court cases confirm the overlap. In City of Indianapolis v. Edmond, 531 U.S. 32, 44 (2000), the Supreme Court relied on the exigent circumstances doctrine in stating that "the Fourth Amendment would almost certainly permit an appropriately tailored roadblock set up to thwart an imminent terrorist attack or to catch a dangerous criminal who is likely to flee by way of a particular route." The Court explained that each of these situations would involve an "emergency" that would cause the "primary purpose" of such a roadblock no longer to be merely "ordinary crime control." Id.; see also id. (stating that the "exigencies created by" the terrorist scenario "are far removed from the circumstances under which authorities might simply stop cars as a matter of course to see if there just happens to be a felon leaving the jurisdiction"). In support of that dicta, the Court cited the decision of the court of appeals in Edmond, which had endorsed roadblocks for similar purposes but relied, not on the exigent circumstances doctrine, but on the "special needs" doctrine of Fourth Amendment law. See Edmond v. Goldsmith, 183 F.3d 659, 662-63 (7 $7^{\text {th }}$ Cir. 1999) (cited in Edmond, 531 U.S. at 44). We see similar blending of the exigent circumstances doctrine and the special needs doctrine in dissenting opinions in Illinois v. Caballes, 543 U.S. 405 (2005). The majority in Caballes held that the use of a narcotics-detection dog during a traffic stop did not constitute a "search" or "seizure" subject to the Fourth Amendment. Id. at 407-10. In dissent, Justice Souter said that he "would treat the dog sniff" as a search subject to the Fourth Amendment. Id. at 84243 (Souter, J., dissenting). Justice Souter noted, however -- in discussing the government's "authority to detect explosives and dangerous chemical or biological weapons that might be carried by a terrorist who prompts no individualized suspicion" -- that "[u]nreasonable sniff searches for marijuana are not necessarily unreasonable sniff searches for destructive or deadly material if suicide bombs are a risk." $I d$. at 843 n.7. Justice Souter did not identify what Fourth Amendment doctrine supported the reasonableness of sniff searches for suicide bombs. Fellow dissenter Justice Ginsburg, however, identified the special needs doctrine as supporting both the suicide-bomb scenario described by Justice 
thus illustrates the overlap between the President's congressionally irreducible, intrinsic power under Article II to respond to genuine national security emergencies and extrinsic limits on that power imposed by the Fourth Amendment. In a "genuine emergency," the President can take immediate action reasonably necessary to protect national security -- even if the action violates statutory restrictions -- and, if the President's action entails a search or seizure (as does presidentially authorized electronic surveillance), exigent circumstances will often excuse ordinary Fourth Amendment requirements. In short, the President's power reasonably to respond to a genuine national security emergency not only is irreducible by Congress but also satisfies the Fourth Amendment -- even if the response entails warrantless, suspicionless searches and seizures -- as long as that response is reasonably justified by the emergency. ${ }^{129}$ The overlap between separation of powers limits and Fourth Amendment limits on the President's power in the Flight 93 scenario is not happenstance. Rather, it reflects an overlap

Souter and the terrorist scenario described by the majority (and justified using the exigent circumstances doctrine) in Edmond. See Caballes, 543 U.S. at 424-25 (Ginsburg, J., dissenting); see also Kia P. v. Mclntyre, 235 F.3d 749, $762\left(2^{\text {nd }}\right.$ Cir. 2000) (holding that state's seizure of a child in order to prevent suspected abuse or neglect could be justified under either the special needs or the exigent circumstances doctrine). In the absence of a genuine national security exigency, even routine protection of national security may justify some types of special needs searches, including ones that occur at the border. See United States v. Flores-Montano, 541 U.S. 149, 152 (2004) (warrantless, suspicionless border searches supported by "the longstanding right of the sovereign to protect itself") (quoting United States v. Ramsey, 431 U.S. 606, 616 (1977)); United States v. Montoya de Hernandez, 473 U.S. 531, 538 (1985) (border searches supported by "Congress' power to protect the nation"); Carroll v. United States, 267 U.S. 132, 154 (1925) ("Travellers may be so stopped in crossing an international boundary because of national self protection... ."). Without extended discussion, I would only note that, in my view, neither the special needs doctrine nor the border search doctrine, standing alone, support the current NSA surveillance program as a whole. The special needs doctrine does not work because of the scope and intrusiveness of the surveillance program; if it passes muster under special needs analysis, just about anything goes -the Fourth Amendment would be gutted. Essentially the same analysis precludes reliance on the border search doctrine. The NSA surveillance program monitors calls and emails between foreign countries and places throughout the United States. Because the surveillance blankets this country, if it is treated as occurring at the border or its "functional equivalent," the border search doctrine would decimate the Fourth Amendment. See Almeida-Sanchez v. United States, 413 U.S. 266, 272-73 (1973) (stating that border searches "may in certain circumstances take place not only at the border itself, but at its functional equivalent as well," such as "a search of the passengers and cargo of an airplane arriving at a St. Louis airport after a nonstop flight from Mexico City"); see also United States v. Ortiz, 422 U.S. 891, 892-93 (1975) (government did not attempt to treat search occurring at fixed checkpoint more than 60 miles from the border as occurring at the "functional equivalent" of the border).

${ }^{129}$ As Chris Slobogin has pointed out, the term "suspicionless" is often used imprecisely to refer to situations that are, in fact, suspicious but that may not involve suspicion associated with any particular individual. See Christopher Slobogin, The World Without a Fourth Amendment, 39 UCLA L. REV. 1, 57, 81-85 (1991). 
between the separation of powers doctrine and Fourth Amendment doctrine. ${ }^{130}$ Our system of separated powers provides a unitary executive to encourage prompt and focused exercises of executive power, especially in foreign affairs. ${ }^{131}$ Yet to prevent abuses of executive power, separation of powers requires the President to obey limits imposed in statutes enacted by Congress (while acting within its powers) and in judgments entered by the federal courts (while acting within their powers). The Fourth Amendment, like the separation of powers doctrine, is designed to prevent abuses of power by any of the three branches. Thus, both the separation of powers and the Fourth Amendment are power-limiting provisions neither of which speaks in absolutes. In a genuine national security emergency, the President needs some room to act unilaterally -- even in defiance of congressional restrictions -- and without the usual Fourth Amendment constraints. Recognition of this unilateral emergency power reflects that neither the separation of powers doctrine nor the Fourth Amendment operates as a "suicide pact."132 As is true of presidential power to ignore generally valid statutes, presidential power to act free of ordinary Fourth Amendment constraints has limits. Specifically, a search that is

\footnotetext{
${ }^{130}$ See Keith, 407 U.S. at 317 (the Fourth Amendment principle that generally requires advance judicial approval of searches "accords with our basic constitutional doctrine that individual freedoms will best be preserved through a separation of powers"); see also Katz v. United States, 389 U.S. 347, (1967) (Douglas, J. concurring) ("In matters where [the President or Attorney General] believe national security may be involved they are not detached, disinterested, and neutral as a court or magistrate must be. Under the separation of powers ..., the Executive Branch is not supposed to be neutral and disinterested... I cannot agree that where spies and saboteurs are involved adequate protection of Fourth Amendment rights is assured when the President and Attorney General assume both the position of adversary-and-prosecutor and disinterested, neutral magistrate."); Raymond Shih Ray Ku, The Founders' Privacy: The Fourth Amendment and the Power of Technological Surveillance, 86 MINN. L. REV. 1325, 1342 (2002) ("[T]he Fourth Amendment and the doctrine of separation of powers share the same goal and are intended to serve the same function" -- namely, "to preclude the exercise of arbitrary power."); $c f$. Timothy Lynch, In Defense of the Exclusionary Rule, 23 HARV. J.L. \& PUB. POL'Y 711, 737 (2000) (arguing that "[t]he exclusionary rule can be justified on the basis of separation of powers principles").

${ }^{131}$ See supra notes _-_ and accompanying text

132 Kennedy v. Mendoza-Martinez, 372 U.S. 144, 160 (1963). On this same "Constitution is not a suicide pact" principle, one can imagine other instances -- besides the exigent circumstances situation -- in which the President might have plenary power to act free of statutory limitations and, at the same time, free of ordinary constitutional constraints. I thank David Kris for this point. See E-mail from David S. Kris, Senior Vice-President \& Deputy General Counsel and Chief Ethics and Compliance Officer, Time Warner, Inc., to Richard Henry Seamon, Professor of Law, University of Idaho College of Law (July 12, 2006 8:49 AM) (on file with author); see also Paulsen, supra note _ , at 1257 (proposing an "overriding principle of constitutional and national self-preservation that operates as a meta-rule of construction and that may even, in cases of extraordinary necessity, trump specific constitutional requirements").
} 
justified at its inception by exigent circumstances violates the Fourth Amendment if conducted in a way that is not reasonably related to the circumstances that justified it in the first place. ${ }^{133}$ And so, police officers who enter a house without a warrant to help a shooting victim cannot stay in the house to search for evidence of crime after they have rendered the help. ${ }^{134}$ Likewise, a wide scale surveillance program that violates an existing statute but that is justified by a national emergency such as $9 / 11$ becomes unjustified as days and weeks pass without further attacks and give the executive branch an opportunity to have Congress consider whether to amend the statute to allow the program. ${ }^{135}$

\section{Summary}

I want to summarize by emphasizing the limited nature of my claim. I claim that precedent suggests that the President has congressionally irreducible power to respond reasonably to respond to genuine national security emergencies. Precedent is suggestive but not conclusive on the existence of this plenary power. Equally important, the precedent suggests the President's "genuine emergency" powers, if any, are limited in scope and duration when Congress has legislated on a matter as to which it and the President share power. In their interstitial nature, the President's powers resemble, and indeed often parallel, the government's

${ }^{133}$ See, e.g., T.L.O., 469 U.S. at 341-42; Mincey v. Arizona, 437 U.S. 385, 393 (1978) ('[A] warrantless search must be strictly circumscribed by the exigencies which justify its initiation ....") (internal quotation marks omitted).

${ }^{134}$ See Mincey, 437 U.S. at 392 (approving lower court cases holding that "the Fourth Amendment does not bar police officers from making warrantless entries and searches when they reasonably believe that a person within is in need of immediate aid," but these holdings did not justify four-day search of murder scene that occurred in the case before the Court).

${ }^{135}$ In commenting on a draft of this article, Louis Fisher asked the fair question how long after 9/11 the President's power to defy FISA lasted. E-mail from Louis Fisher, supra note _. Lincoln acted in April 1861 and didn't address Congress until it returned several months later. He notes that, when President Lincoln waited until several months after Congress returned from recess to seek legislation authorizing Lincoln's emergency actions (including suspension of the writ of habeas corpus) in April 1861. Id.; see also Fisher, supra note _ , at 260-61. I agree with the standard that Dr. Fisher proposes: When Congress is in session, the President must go to Congress as soon as possible. In the case of $9 / 11$, that date came less than one week after 9/11, for that is how quickly the Administration was able to draft and present to Congress the bill later enacted as the Patriot Act. See 9/11 REPORT, supra note _, at 328; see also Administration's Draft Anti-Terrorism Act of 2001: Hearing Before the Judiciary Comm. of the House of Representatives, $107^{\text {th }}$ Cong. $67-90$ (Sept. 24, 2001) (reproducing Administration's proposed bill). 
power under "exigent circumstances" to conduct searches and seizures free from the traditional

Fourth Amendment requirements of a warrant and individualized probable cause. ${ }^{136}$ The parallel reflects the pragmatic balance between strong executive power and safeguards against executive abuses that underlie both separation of powers doctrine and Fourth Amendment doctrine.

III. Analysis of the NSA Program As an Exercise of the President's Genuine National Security Emergency Powers

A. Whether the NSA Program Falls Within the President's Power Even Though the Program Violates FISA

As discussed above, precedent suggests that the President has congressionally irreducible power to take immediate action reasonably necessary to respond to a genuine national security emergency; that power is limited, however, by the legislative framework within which it is exercised and by its exigent nature. The current NSA program exceeds those limits.

Let us assume that in the days and weeks after the 9/11 attacks the President could have established a "program" of domestic, electronic surveillance outside FISA. The President's power to maintain such a program, which violated a facially valid statute, subsided as weeks passed without further attacks and provided "time for deliberation" ${ }^{137}$ within a system of civilian government that continued to function. ${ }^{138}$ Indeed, deliberations on appropriate responses to 9/11 did occur within and among the executive branch and Congress. The result was enactment of the PATRIOT Act, which expanded surveillance power by, among other

\footnotetext{
${ }^{136}$ Thus, I am not making the argument that a court recently understood the government to be making in defense of the NSA program; I do not argue that the President "has been granted the inherent power to violate not only the laws of the Congress but [also] the ... Fourth Amendment." ACLU v. NSA, 2006 WL 2371463 , at *25.

${ }^{137}$ Hamdi, 542 U.S. at 552.

${ }^{138}$ Ex parte Milligan, 71 U.S. 2, 80 (1866) (stating that military tribunals could "furnish a substitute for the civil authority" if "in foreign invasion or civil war, the [civil] courts are actually closed, and it is impossible to administer criminal justice according to law"); cf. Hamdan v. Rumsfeld, 126 S. Ct. 2749, 2799 (2006) (opinion of Breyer, J., concurring) (rejecting dissent's argument that Court's decision invalidating Presidential order establishing military tribunals threatened national security: "Where, as here, no emergency prevents consultation with Congress, judicial insistence upon that consultation does not weaken our Nation's ability to deal with danger.").
} 
changes, amendments to FISA. ${ }^{139}$ It is hard for the President to argue it was reasonably necessary to establish a far-ranging surveillance "program" in defiance of FISA when the President did not first attempt to change FISA to avoid the need to violate that statute. ${ }^{140}$ True, FISA has shortcomings. The shortcomings reflect changes in surveillance technology and in international terrorism. Those shortcomings could very well justify surveillance outside FISA -- even today -- if the President reasonably determines that, in a particular instance, it is reasonably necessary to depart from FISA. Specifically, FISA may have three shortcomings that could create "genuine emergencies" justifying event-specific departures from FISA.

First, it may take too long to get a FISA surveillance order. ${ }^{141}$ True, the Attorney General can authorize "emergency orders" approving FISA surveillance without prior court approval. ${ }^{142}$

\footnotetext{
${ }^{139}$ United and Strengthening America by Providing Appropriate Tools Required to Intercept and Obstruct Terrorism Act of 2001, Pub. L. No. 107-56, §§ 206-208, 214, 215, 218 \& 225, 115 Stat. 272, 282-83, 287$88,291,295-96$ (2001) (codified in scattered sections of 50 U.S.C.).

${ }^{140}$ See supra note _ and accompanying text (arguing that President had power to act only while there was no time for deliberation). One argument that the President has made is that the terrorists might have been alerted if the President had consulted with Congress about the NSA surveillance program. This argument is difficult to analyze because so little relevant information is publicly available. I do not wish to reject the argument out of hand, however.

${ }^{14}$ The DOJ White Paper, supra note _, at 18, summarizes the typical FISA process:
}

As a general matter, the statute requires that the Attorney General approve an application for an order from a special court composed of Article III judges and created by FISA-the Foreign Intelligence Surveillance Court (“FISC"). See 50 U.S.C. §§ 18031804. The application must demonstrate, among other things, that there is probable cause to believe that the target is a foreign power or an agent of a foreign power. See id. $\S 1805(a)(3)(A)$. It must also contain a certification from the Assistant to the President for National Security Affairs or an officer of the United States appointed by the President with the advice and consent of the Senate and having responsibilities in the area of national security or defense that the information sought is foreign intelligence information and cannot reasonably be obtained by normal investigative means. See id. § 1804(a)(7). FISA further requires the Government to state the means that it proposes to use to obtain the information and the basis for its belief that the facilities at which the surveillance will be directed are being used or are about to be used by a foreign power or an agent of a foreign power. See id. § 1804(a)(4), (a)(8).

14250 U.S.C. § 1805(f) ("Emergency orders") provides in relevant part:

Notwithstanding any other provision of this subchapter, when the Attorney General reasonably determines that -- 
But this statutory emergency authority has drawbacks. The Attorney General must personally determine the existence of both an emergency exists and that the factual basis for the issuance of an orders. ${ }^{143}$ Until he or she does so, emergency surveillance cannot occur. ${ }^{144}$ NSA, however, may need to start surveillance the instant that NSA determines the surveillance is justified, without waiting for Attorney General authorization. ${ }^{145}$ Furthermore, the Attorney General is only one person, and he or she may be called upon personally and very quickly to make dozens or hundreds of "emergency" determinations. The Attorney General could become a bottleneck. Finally, the government must advise the FISA court of each emergency order and apply within 72 hours for a surveillance order from the court to ratify the attorney general's

(1) an emergency situation exists with respect to the employment of electronic surveillance to obtain foreign intelligence information before an order authorizing such surveillance can with due diligence be obtained; and

(2) the factual basis for issuance of an order under this subchapter to approve such surveillance exists;

he may authorize the emergency employment of electronic surveillance is a judge having jurisdiction under section 1803 of this title is informed by the Attorney General or his designee at the time of such authorization that the decision has been made to employ emergency electronic surveillance and if an application in accordance with this subchapter is made to that judge as soon as practicable, but not more than 72 hours after the Attorney General authorizes such surveillance. If the Attorney General authorizes such emergency employment of electronic surveillance, he shall require that the minimization procedures required by this subchapter for the issuance of a judicial order be followed. In the absence of a judicial order approving such electronic surveillance, the surveillance shall terminate when the information sought is obtained, when the application for the order is denied, or after the expiration of 72 hours from the time of authorization by the Attorney General, whichever is earliest.

${ }^{143} 50$ U.S.C. § 1805(f)(1) \& (2); Moschella Letter of Mar. 24, 2006, supra note _, encl. at 12 (stating that Attorney General must "personally" determine that factual basis for emergency FISA surveillance exists). 144 See Moschella Letter of Mar. 24, 2006, supra note _, encl. at 39 ("[A]s a practical matter, it is necessary for NSA intelligence officers, NSA lawyers, Justice Department lawyers, and the Attorney General to review a matter before even emergency surveillance would begin.").

${ }^{145}$ See Alberto R. Gonzales, Prepared Remarks at the Georgetown University Law Center (Jan. 24, 2006), available at http://www.usdoj.gov/ag/speeches/2006/ag_speech_0601241.html:

[T] he optimal way to achieve the necessary speed and agility is to leave the decisions about particular intercepts to the judgment of professional intelligence officers, based on the best available intelligence information. They can make that call quickly. If, however, those same intelligence officers had to navigate through the FISA process for each of these intercepts, that would necessarily introduce a significant factor of DELAY, and there would be critical holes in our early warning system. 
emergency order. ${ }^{146}$ This supposedly expedited application process, required for every

emergency order, could keep dozens of government lawyers employed on a continual fire drill

without coming close to achieving the instantaneous authorization that is sometimes required for national security surveillance.

Second, the standards for getting FISA surveillance orders may be too high. NSA monitors phone calls and emails into and out of the United States involving people whom NSA has a "reasonable basis" for believing are associated with al Qaeda. ${ }^{147}$ These people may not be "agents of foreign power" who can be targeted under FISA. ${ }^{148}$ Indeed, the person in the United States whose phone calls or emails are monitored may be entirely innocent, if it is the person outside the U.S. who is associated with al Qaeda and who triggers NSA surveillance. ${ }^{149}$ To cite another example, perhaps the person in the U.S. who is being monitored is associated with al Qaeda but the association does not make that person a foreign agent. ${ }^{150}$ Even so, the government may have good reason to monitor the communication.

${ }^{146} 50$ U.S.C. $\S 1805(f)$.
${ }^{147}$ See DOJ White Paper, supra note __, at 5 ("[T]he Attorney General [has] elaborated and explained that in order to intercept a communication, there must be 'a reasonable basis to conclude that one party to the communication is a member of al Qaeda, affiliated with al Qaeda, or a member of an organization affiliated with al Qaeda.' Press Briefing by Attorney General Alberto Gonzales and General Michael Hayden, Principal Deputy Director for National Intelligence, available at http://www.whitehouse.gov/news/releases/2005/12/20051219-1.html (Dec. 19, 2005) (statement of Attorney General Gonzales).").

${ }^{148} 50$ U.S.C. § 1801(b) (defining "agent of a foreign power"); see also id. § 1805(a)(3) (requiring judge to find "probable cause" that target of proposed FISA surveillance "is a foreign power or an agent of a foreign power").

149 Senate Hearing of Feb. 28, 2006, supra note _, at _ (testimony of former CIA Director James Woolsey) ("Suppose Al Qaida calls someone in the united States, and it's a false flag operation, and they pretend to be Hezbollah to get him to do something. Are they an agent -- is that probable cause to believe they're an agent of Al Qaida? I don't think so."); Douglas Waller, A Better Way to Eavesdrop?, TIME, Feb. 2, 2006 (quoting "administration official" as stating that "you have this amorphous group of people around the world who are all calling people in the U.S. You may not know who they're calling in the U.S., but you know the person making the call is a bad guy. ... But FISA doesn't fit that situation."); Richard A. Posner, Wire Trap, NEW REPUBLIC, Feb. 6, 2006, at 15 (NSA program is apparently designed to fill gap left by FISA "by conducting warrantless interceptions of communications in which one party is in the United States ... and the other party is abroad and suspected of being a terrorist.").

${ }^{150}$ See Seamon \& Gardner, supra note _ , at 345 (footnotes omitted):

[FISA] classifies a U.S. person as a foreign agent based on their "knowing" involvement, "for or on behalf of a foreign power," in (1) "'clandestine intelligence gathering activities' [that] involve or may involve violations of Federal criminal law'; (2) "other clandestine 
Third, FISA orders could be too narrow. FISA authorizes surveillance of one target at a time. $^{151}$ The government, however, sometimes needs to conduct wholesale surveillance -- for example, by monitoring phone calls to all persons in the United States from particular individuals outside the U.S. ${ }^{152}$ Wholesale surveillance may very well violate FISA but be reasonably necessary in a genuine national security emergency, such as when the government has strong evidence that someone outside the U.S. is planning terrorist attacks on a U.S. target with accomplices inside the U.S. ${ }^{153}$

intelligence activities," "pursuant to the direction of an intelligence service or network of a foreign power," "which ... involve or are about to involve a violation of the criminal statutes of the United States"; (3) "sabotage or international terrorism [as defined elsewhere in the FISA] ... or activities that are in preparation therefore"; (4) entering or remaining in the United States "under a false or fraudulent identity" or (5) aiding or abetting, or conspiring to engage in, any of the first three categories of activities listed in this sentence. Thus, to find probable cause that a U.S. person is an "agent of a foreign power," the judge usually must find evidence of conduct that is a crime or likely to be a crime.

See also McCarthy, supra note _, at 90 (referring to the "relatively narrow portion of the overall al Qaeda-related communications" covered by FISA); Posner, supra note __, at 16 ("[T] he problem with fisa is that the surveillance it authorizes is unusable to discover who is a terrorist, as distinct from eavesdropping on known terrorists .... Even to conduct fisa-compliant surveillance of non-U.S. persons, you have to know beforehand whether they are agents of a terrorist group, when what you really want to know is who those agents are.").

${ }^{151}$ Senate Hearing of Feb. 28, 2006, supra note _, at _ (testimony of former CIA Director James Woolsey) ("The one spy at a time surveillance systems of the Cold War, including FISA, through courts, are not designed to deal with fast-moving battlefield electronic mapping -- in which an AI Qaida or a Hezbollah computer might be captured which contains a large number of e-mail addresses and phone numbers which would have to be checked out very promptly. An attorney general, on a 72-hour basis or a FISA court, simply cannot go through the steps that are set out ... in time to deal with this type of situation").

${ }^{152}$ See Posner, supra note _, at 16 (surveillance would run up against FISA if government domestically monitored all international phone calls to a phone number in the United States that was discovered once to have been called by a terrorist suspect abroad, or if government, more broadly, used computers domestically to scan all electronic communications for suspicious messages); K. A. Taipale, Whispering Wires and Warrantless Wiretaps: Data Mining and Foreign Intelligence Surveillance, N.Y.U. REV. L. \& SECURITY, No. VII Supl. Bull. on L. \& Sec.: The NSA and the War on Terror, at 4-6 (Spring 2006) (discussing need for automated, programmatic surveillance of electronic communications' contents and traffic patterns), available at http://whisperingwires.info/.

${ }^{153}$ The government can also avoid FISA by conducting electronic surveillance that falls outside FISA's definition of "electronic surveillance." The definition does not, for example, cover surveillance of a "United States person" if the surveillance is conducted outside the United States and does not "intentionally target[] that United States person." 50 U.S.C. $\S 1801(f)$. Thus, the government would not be subject to FISA if it targeted persons who are located abroad -- even U.S. persons -- if the surveillance occurs abroad. If conducted inside the United States, however, the surveillance would be subject to FISA. See 50 U.S.C. § 1801(f)(2) (defining "electronic surveillance" to include, with an exception not pertinent here, "the acquisition by an electronic, mechanical, or other surveillance device of the contents of any wire or 
In sum, the President may have power to authorize surveillance "outside FISA" in situations presenting a "genuine emergency." That power, however, exists only when national security exigencies make it reasonably necessary to ignore FISA. Even so, the power justifies surveillance outside FISA even today, to the extent FISA's shortcomings create exigent circumstances precluding resort to the FISA process. This residual power does not support the current NSA surveillance "program," which authorizes wholesale departure from FISA.

B. Whether the NSA Program Violates the Fourth Amendment Because Surveillance Under the Program Occurs Without a Warrant or Traditional Probable Cause

Before Congress enacted FISA in 1978, several lower federal courts upheld warrantless electronic surveillance conducted for national security purposes. ${ }^{154}$ Those courts interpreted the Fourth Amendment to create an exception to the warrant requirement for searches conducted for foreign intelligence purposes. ${ }^{155}$ The government has relied on these cases to argue that the current NSA program of domestic surveillance does not violate the Fourth Amendment even though it occurs without a warrant or probable cause to believe the surveillance will reveal evidence of crime. ${ }^{156}$ Opponents of the current NSA program counter that these cases are

radio communication to or from a person in the United States, without the consent of any party thereto, if such acquisition occurs in the United States"); see also NSA Debate: Federalist Society: Rivkin v. Levy (posted on Jan. 23, 2006) (remark by David Rivkin), available at http://www.freerepublic.com/focus/fnews/1563282/posts.

${ }^{154}$ Sealed Case, 310 F.3d at 742 ("[A]ll the other courts to have decided the issue [have] held that the President did have inherent authority to conduct warrantless searches to obtain foreign intelligence information."); see United States v. Truong Dinh Hung, 629 F.2d 908, 913 (4 ${ }^{\text {th }}$ Cir. 1980) ("[T]he Executive Branch need not always obtain a warrant for foreign intelligence surveillance."); United States v. Butenko, 494 F.2d 593, 606 ( $3^{\text {rd }}$ Cir. 1974) (en banc) ("[A] warrant prior to a search is not an absolute prerequisite in the foreign intelligence field when the President has authorized surveillance"); United States v. Brown, 484 F.2d 418, 426 (5 ${ }^{\text {th }}$ Cir. 1973) ("[T]he President may constitutionally authorize warrantless wiretaps for the purpose of gathering foreign intelligence."). But cf. Zweibon, 516 F.2d at 613-14 (plurality opinion of Wright, J.) (stating in dicta, "[A]n analysis of the policies implicated by foreign security surveillance indicates that, absent exigent circumstances, all warrantless surveillance is unreasonable and therefore unconstitutional."); see also id. at 651 ("[O]ur analysis would suggest that, absent exigent circumstances, no wiretapping in the area of foreign affairs should be exempt from prior judicial scrutiny, irrespective of the justification for the surveillance or the importance of the information sought.").

${ }^{155}$ See, e.g., Truong, 629 F.2d at 913 ("For several reasons, the needs of the executive are so compelling in the area of foreign intelligence ... that a uniform warrant requirement would ... unduly frustrate the President in carrying out his foreign affairs responsibilities.") (internal quotation marks omitted).

${ }^{156}$ See, e.g., DOJ White Paper, supra note _, at 8 ("[E]very federal appellate court to rule on the question has concluded that, even in peacetime, the President has inherent constitutional authority, 
inapposite because they concern surveillance conducted before FISA was enacted. ${ }^{157}$ Thus, the opponents believe that FISA's enactment affects Fourth Amendment analysis. Neither opponents nor supporters of the NSA program, however, elaborate on how FISA affects Fourth Amendment analysis. This portion of the article examines that issue. I believe that FISA influences any Fourth Amendment analysis of the NSA program and should carry particular weight in the courts' analysis of the program.

First, it changes the legal landscape within which the Fourth Amendment reasonableness of the NSA program will be judged. ${ }^{158}$ Prior to FISA, the alternative to conducting electronic surveillance for national security purposes without a warrant was to seek a warrant for a physical search using the warrant application process used by prosecutors to search for evidence of crime. ${ }^{159}$ That process caused problems because it was designed for physical searches, not electronic surveillance, and for criminal investigations, not for national security surveillance. ${ }^{160}$ With the ordinary criminal warrant process as an alternative, warrantless national security surveillance might have been reasonable. Warrantless surveillance is not necessarily reasonable when the alternative to it is the FISA process that Congress engineered with electronic surveillance and national security in mind. Thus, experience under FISA could establish that the current NSA program is unreasonable, and therefore violates the Fourth Amendment, even though the same program might have been

consistent with the Fourth Amendment, to conduct searches for foreign intelligence purposes without securing a judicial warrant.").

${ }^{157}$ See, e.g., ABA Task Force Report on NSA Surveillance, supra note _, at 13 (observing, in response to government's reliance on pre-FISA case law, that "FISA was enacted precisely because, prior to FISA, prior presidents had repeatedly abused" their power).

${ }^{158}$ See, e.g., Samson v. California, 2006 WL 1666974 (June 19, 2006) ("[U]nder our general Fourth Amendment approach, we examin[e] the totality of the circumstances to determine whether a search is reasonable within the meaning of the Fourth Amendment.") (internal quotation marks omitted).

${ }^{159}$ See generally, e.g., Fed. R. Crim. P. 41 (governing process for federal law enforcement officers and government attorneys to get search warrants).

${ }^{160}$ See Truong, 629 F.2d at 913-15 (decision involving pre-FISA surveillance holding that "because of the need of the executive branch for flexibility, its practical experience, and its constitutional competence, the courts should not require the executive to secure a warrant each time it conducts foreign surveillance"); Amicus Memo at 42, In re Warrantless Electronic Surveillance, supra note _ (arguing that the concerns identified in Truong are largely alleviated by FISA, including its creation of a specialized court with procedures for expedited consideration of applications for surveillance orders). 
reasonable prior to FISA. In short, determining whether warrantless NSA surveillance is reasonable requires a consideration of the alternatives. FISA has created an alternative that, experience show, facilitates the process of getting judicial approval for national security surveillance. Thus, the existence of FISA and experience under the FISA bears on the reasonableness of proceeding without resort to that process in somewhat the same way as rules authorizing telephonic warrants bears on the reasonableness of police proceeding without a warrant. ${ }^{161}$

So, too, the existence of FISA bears on Fourth Amendment analysis in essentially the same way as it bears on separation of powers analysis. To the extent that FISA provides a process adequate for conducting surveillance in a genuine national security emergency, the government's failure to use that process is unreasonable. To the same extent, the failure to use that process cannot be justified by the President's congressionally irreducible power to violate a statute when reasonably necessary to respond to a genuine national security emergency. ${ }^{162}$

FISA would thus be relevant to any Fourth Amendment analysis of the NSA program. For three additional reasons, it deserves particular weight in judicial analysis of the program.

First, FISA generally falls within Congress's power to regulate domestic surveillance for foreign intelligence information. That power comes from the Commerce Clause, to the extent that the surveillance involves interception of information that travels through channels of interstate or foreign commerce such as telephone lines. ${ }^{163}$ Additional power flows from

${ }^{161}$ See Steagald v. United States, 451 U.S. 204, 222 (1981) (observing that the inconvenience of obtaining a warrant to arrest a suspect in a third party's home is "simply not that significant" because of, among other reasons, availability of telephonic warrants); cf. Minnesota v. Dickerson, 508 U.S. 366, 382 (1993) (Scalia, J., concurring) ("[E]ven if a 'frisk' prior to arrest would have been impermissible in 1791 [when the Fourteenth Amendment was adopted], ... perhaps it is only since that time that concealed weapons capable of harming the interrogator quickly and from beyond arm's reach have become common -- which might alter the judgment of what is 'reasonable' under the original standard."). 162 See supra notes ____ and accompanying text.

163 See U.S. CoNST. art. I, § 8, cl. 3; Nardone v. United States, 302 U.S. 379, 381-85 (1937) (construing federal statute to bar federal agents from divulging communications intercepted by telephone taps; supposing that Congress enacted the statute to enforce "the guaranty against practices and procedures violative of privacy, embodied in the Fourth and Fifth Amendments of the Constitution"); see also supra 
congressional powers associated with war and foreign affairs as amplified by the Necessary and Proper Clause. ${ }^{164}$ Indeed, the executive branch has never questioned that FISA generally falls within Congress's power, except to the extent that it infringes on the President's congressionally irreducible power under the Constitution. ${ }^{165}$

\section{Second, FISA not only falls within Congress's power but also represents Congress's} careful attempt to enforce the Fourth Amendment. ${ }^{166}$ Congress considered foreign intelligence

notes ___ and accompanying text (discussing Congress's power to regulate executive's gathering of foreign intelligence).

164 See U.S. ConST. art. I, § 8. cl. 10-16, 18.

165 See Seamon \& Gardner, supra note _, at 337 n.70 (citing legislative history); see also Keith, 407 U.S. at 338 n.2 ("[T]he United States does not claim that Congress is powerless to require warrants for surveillances that the President otherwise would not be barred by the Fourth Amendment from undertaking without a warrant."). In commenting on a draft of this article, Judge Posner observed that -unlike Section 5 of the Fourteenth Amendment, which empowers Congress to pass laws applicable to the states enforcing substantive constitutional provisions, "[t]here is no corresponding authorization for Congress to pass laws enforcing ... the Fourth Amendment" against the federal government. E-mail from Judge Posner, supra note _. In my view Congress does have power - under the Necessary and Proper Clause -- legislatively to prescribe its judgments on Fourth Amendment reasonableness when Congress is regulating federal officials' enforcement (execution) of laws that Congress enacted under other enumerated powers. See U.S. CoNST. art. I, § 8. cl. 18 (empowering Congress to enact laws necessary and proper "for carrying into Execution" not only other legislative powers but, in addition, "all other Powers vested by this Constitution in the Government of the united States, or in any Department or Officer thereof"). When Congress in the FISA authorized federal agents to conduct foreign intelligence surveillance, Congress was entitled to limit this authority -- granted by Congress itself -- in a way that, in Congress's judgment, corresponded to Fourth Amendment limits. Cf. Thomas C. Berg, The Constitutional Future of Religious Freedom Legislation, 20 U. Ark. Little Rock L.J. 715, 728-38 (1998) (making a similar point with respect to Congress's power to enforce Free Exercise Clause against federal government's actions). Granted, Congress's ability to limit the scope of its own grants of power to federal law enforcement agents differs from Congress's ability to limit the scope of the President's exercise of his or her constitutional powers through executive branch agents. Precisely because of that difference, I argue in this article that FISA violates the separation of powers doctrine if FISA is construed to prevent the President from taking action necessary in response to a genuine national security emergency. Congress cannot infringe on the President's inherent, congressionally irreducible power to respond to genuine national security emergencies even when Congress seeks to enforce what it regards as restrictions compelled by the Fourth Amendment. A power in Congress to enforce the Fourth Amendment outside the plenary presidential power is a power to enforce, not a power to define, the substance of the Fourth Amendment. But Congress's exercise of this enforcement power should affect judicial analysis of Fourth Amendment reasonableness, at least when Congress so carefully considers Fourth Amendment concerns as did the Congress that enacted FISA. The resulting legislation supplies important evidence on both the governmental interests and the privacy interests that underlie reasonableness analysis. This conclusion finds support in the case law cited supra in note 157.

${ }^{166}$ See, e.g., S. REP. No. 95-701, at 13 (1978) (bill enacted as FISA "embodies a legislative judgment [about the] ... procedural safeguards necessary to insure that electronic surveillance ... conforms to the fundamental principles of the fourth amendment"); S. REP. No. 95-604, at 7-8 (1977) (bill responded to finding by Church Committee that prior executive branch surveillance supposedly conducted for national security purposes "seriously infringed the fourth Amendment Rights of both the targets and those with whom the targets communicated") (quoting Senate Comm. To Study Governmental Operations with 
surveillance for six years and held as many hearings before enacting FISA. ${ }^{167}$ Congress devoted much of that time to crafting legislation that balanced national security needs against Fourth Amendment concerns. ${ }^{168}$ Throughout the process, Congress consulted with the Department of Justice. ${ }^{169}$ FISA may not be perfect -- especially after 30 years of changes in technology and foreign threats -- and it may not reflect the only way to strike the balance commanded by the Fourth Amendment -- but it certainly does represent Congress's judgment of how the balance should be struck, and Congress made that judgment carefully and based on full information. ${ }^{170}$

Third, courts should respect legislation, such as FISA, that generally falls within Congress's powers and is carefully designed to protect Fourth Amendment rights against executive surveillance. ${ }^{171}$ By respecting such legislation, courts encourage legislative enforcement efforts. Those efforts deserve judicial support because they can produce

Respect to Intelligence Activities, Final Report on Intelligence Activities and the Rights of Americans, S. REP. No. 94-755, book III, at 332 (1976) (Church Committee Report)).

${ }^{167}$ See S. REP. No. 95-604 at 7 (1977) (observing that hearings on bill enacted as FISA "were the sixth set of hearings on warrantless wiretapping in as many years").

${ }^{168}$ H.R. REP. No. 95-1283, pt. I, at 22 (1978) ("In drafting this bill, the committee has carefully weighed the need "for foreign intelligence electronic surveillance"] against the privacy and civil liberties interests.").

${ }^{169}$ See H.R. Rep. No. 95-1238, pt. I, at 13-14 (1978) (describing Justice Department involvement).

${ }^{170} \mathrm{Cf}$. Ku, supra note _, at 1360 ("Laws prohibiting certain forms or means of information gathering ... should limit executive power and define at least minimum levels of privacy and security protected by the Fourth Amendment.").

${ }^{171}$ Cf. United States v. Watson, 423 U.S. 411, 415-17 (1976) (giving weight to federal statutes authorizing warrantless felony arrests in determining their reasonableness under Fourth Amendment); AlmeidaSanchez v. United States, 413 U.S. 266, 290 (1973) ("The Court has been particularly sensitive to the [Fourth] Amendment's broad standard of 'reasonableness' when ... authorizing statutes permitted the challenged searches."); see also Keith, 407 U.S. at 323-24 (discussing Congress's power to regulate surveillance for national security); Dalia v. United States, 441 U.S. 238, 250 n.9 (1979) (noting that Title III "serves a substantial public interest" by giving government surveillance powers while "carefully prescribing" those powers to protect privacy interests); Bivens v. Six Unknown Named Agents of the Federal Bureau of Narcotics, 403 U.S. 388, 397 (1971) (appearing to invite Congress to create remedies to enforce Fourth Amendment rights to displace court created remedy); Colonnade Catering Corp. v. United States, 397 U.S. 72, 77 (1970) (considering traditionally close supervision of liquor industry, "Congress has broad authority to fashion standards of reasonableness for searches and seizures" in that industry); Davis v. United States, 328 U.S. 582, 605-06 (1946) (detailing history of federal statutes evidencing Congress's "watchfulness against the dangers of police abuses" in exercise of search and seizure powers); Olmstead v. United States, 277 U.S. 438, 465-66 (1928) (stating that, although Fourth Amendment did not apply to wiretapping involved there, "Congress may, of course, protect the secrecy of telephone messages"); Kerr, supra note at 805-06 (arguing that legislatures, rather than courts, should "provide the primary rules governing law enforcement investigations involving new technologies"). 
legislative rules that facilitate judicial enforcement. ${ }^{172}$ FISA does this, for example, by generally requiring advance judicial approval for FISA surveillance. ${ }^{173}$ Some statutes deserve judicial skepticism because they expand executive power with little attention to individual rights. ${ }^{174}$ FISA does not fall within that description; it restricted executive power to enforce Fourth Amendment safeguards. ${ }^{175}$

Legislative rules enforcing the Fourth Amendment can facilitate judicial enforcement not only by requiring prior judicial authorization for executive surveillance but also by prescribing substantive standards for the surveillance. Indeed, FISA prescribes an exhaustively considered standard for surveillance. ${ }^{176}$ Legislatively prescribed standards for surveillance can benefit from the legislature's ability to gather information relevant to balancing government interests in surveillance against individual privacy interests. ${ }^{177}$ Furthermore, legislatures may be able to make clearer standards than those made by courts. Clear rules, in turn, help officials obey the law and give the public notice of what privacy intrusions are authorized. ${ }^{178}$ In addition, the

172 See Anthony G. Amsterdam, Perspectives On the Fourth Amendment, 58 MiNN. L. REV. 349, 416-29 (1974) (articulating and defending a rule under which, "[u]nless a search or seizure is conducted pursuant to and in conformity with either legislation or police departmental rules and regulations, it is an unreasonable search and seizure prohibited by the fourth amendment"); see also Peter P. Swire, Katz Is Dead. Long Live Katz, 102 MICH. L. REV. 904, 930 (2004) (referring to "the catalog of instances where the Supreme Court worked collaboratively with congress to create surveillance rules"); Kerr, supra note __, at 867-89 (arguing that "legislatures often are better situated than courts to protect privacy in new technologies"). But cf. Solove, supra note _, at 761 (arguing that legislative rules are not superior to Fourth Amendment protections articulated by courts).

${ }^{173} 50$ U.S.C. $\S \S 1802 \& 1804$.

174 See generally Donald A. Dripps, Criminal Procedure, Footnote Four, and the Theory of Public Choice: Or, Why Don't Legislatures Give a Damn About the Rights of the Accused?, 44 SYRACUSE L. REV. 1079, 1089 (1993) (arguing that "legislators undervalue the rights of the accused ... [because] a far larger number of persons, of much greater political influence, rationally adopt the perspective of a potential crime victim rather than the perspective of a suspect or defendant").

${ }_{175}$ See Seamon \& Gardner, supra note _, at 337 \& n.70 (citing legislative history showing executive branch's awareness that FISA restricted executive power).

${ }_{177}^{176}$ See id. at 427-435 (discussing legislative history of FISA's surveillance standard).

$177 \mathrm{Ku}$, supra note _, at 1375 (legislatures are "better able to develop a factual record with respect to the nuances and details of new [surveillance] technologies and their costs and benefits").

${ }^{178}$ Cf. New York v. Burger, 482 U.S. 691, 703 (1987) (statutory program providing for warrantless administrative searches "must perform the two basic functions of a warrant: it must advise the [person subject to the search] ... that the search is being made pursuant to law and has a properly defined scope, and it must limit the discretion of the inspecting officers"); Amsterdam, supra note _ , at 418 (arguing that police-made rules would be clearer than judge-made rules); but cf. United States v. Grubbs, $126 \mathrm{~S}$. Ct. 
public may better accept surveillance rules made by their elective representatives than rules made by unelected federal judges. ${ }^{179}$ Legislative rules can be revised if they become unacceptable to the public. ${ }^{180}$ Legislation can restrict the use of information derived from surveillance, ${ }^{181}$ and impose sanctions for violations of those restrictions, including criminal sanctions. ${ }^{182}$ In short, courts have good reasons to give significant weight to legislation that enforces Fourth Amendment limits on surveillance. ${ }^{183}$

On the flip side, allowing the President to ignore statutory restrictions on surveillance encourages executive lawlessness. Courts should discourage that behavior by preferring Fourth Amendment interpretations that encourage the executive branch to collaborate with the legislature to frame such rules, rather than defying them. After all, how is the public to feel when an Act of Congress supposedly provides the "exclusive" authority for a specified type of surveillance yet they learn that a program exists "outside" that authority and has been going on for years ${ }^{184}$ Such a situation is likely to undermine public confidence that the nation's leaders

1494, 1501 (2006) (rejecting the argument that victim of search is entitled to a copy of warrant before search begins in order to ensure searching officers stay within scope of warrant).

${ }^{179}$ NSA III: Wartime Executive Powers and the FISA Court: Hearing Before the Sen. Comm. On the Judiciary, $109^{\text {th }}$ Cong. __ (Mar. 28, 2006) [hereinafter Senate Hearing of Mar. 28, 2006] (testimony of Morton Halperin, Senior Fellow, Center for American Progress) (notice to U.S. citizens of "the rules under which they may be subject to surveillance by their government in the name of national security" are necessary "to secure the necessary support of the American people for the appropriate steps needed to reduce the risk of terrorist attacks"), available at http://judiciary.senate.gov/testimony.cfm?id=1825\&wit_id=5189.

${ }^{180}$ See Senate Hearing of Mar. 28, 2006, supra note __, at _ (prepared statement of Morton Halperin, Senior Fellow, Center for American Progress, and Exec. Director, Open Society Policy center) (notice to public of rules for surveillance is necessary so that, if the public "believe[s] the law requires reconsideration, they can seek change by lobbying the president and the Congress and by exercising their right to vote").

${ }^{181}$ See 50 U.S.C. $§ 1806$ (regulating the use of information obtained in FISA surveillance); see also Ferguson v. City of Charleston, 532 U.S. 67, 78 (2001) (dissemination to third parties of results of government-conducted drug tests caused drug testing program for pregnant women to involve a "far more substantial" invasion of privacy than prior cases in which dissemination of drug test results was more restricted).

182 See, e.g., 50 U.S.C. $\S 1809$ (FISA provision prescribing criminal penalties); cf. Amsterdam, supra note , at 428-29 (arguing that police-made rules could include administrative sanctions).

${ }^{183}$ Cf. Hamdi, 542 U.S. at 536 ("Whatever power the United States Constitution envisions for the Executive in its exchanges with other nations or with enemy organizations in times of conflict, it most assuredly envisions a role for all three branches when individual liberties are at stake.").

${ }^{184}$ See supra notes ___ and accompanying text. At least before FISA, Title III notified the public notice that the President might have power to conduct surveillance outside statutory constraints. See supra 
obey the rule of law. It undermines faith in the legislative branch's willingness and ability to check executive abuse and in the President's willingness to abide by legislative restrictions.

To implement respect for legislation, such as FISA, that is carefully designed to enforce the Fourth Amendment, courts should presume treat surveillance "outside FISA" violates the Fourth Amendment. After all, FISA reflects Congress's judgment, formed with extensive input from the executive branch, of what the Fourth Amendment requires. Treating FISA violations as presumptive Fourth Amendment violations simply reflects that, when surveillance violates a statute that Congress and the Executive Branch designed to enforce the Fourth Amendment, the surveillance is likely to violate the Fourth Amendment. Thus, this presumption of unconstitutionality works like the presumption that the warrantless search of a home violates the Fourth Amendment. ${ }^{185}$ The latter presumption reflects that warrantless searches of homes are likely to violate the Fourth Amendment. ${ }^{186}$ In addition to this probabilistic basis for the presumption against warrantless searches of home, that presumption encourages police to obtain warrants, just as the presumptive unconstitutionality of surveillance outside FISA encourages compliance with FISA. ${ }^{187}$ In short, both presumptions are rooted in common sense and further the Fourth Amendment's function of preventing abuses of power.

Of course, the presumptive unconstitutionality of surveillance outside FISA may be overcome. First and foremost, the presumption is overcome by proof that the surveillance was

note _ (describing provision in Title III disclaiming that it limited President's power to protect national security).

185 See Groh v. Ramirez, 540 U.S. 551, 564 (2004) (stating the presumption against constitutionality of warrantless searches of the home).

${ }^{186}$ Kyllo v. United States, 533 U.S. 27, 31 (2001) ("With few exceptions, the question whether a warrantless search of a home is reasonable and hence constitutional must be answered no.").

${ }^{187}$ See Illinois v. Gates, 462 U.S. 213, 236 (1983) (warrant preference discourages police from acting without warrant). In contrast to the presumption of unconstitutionality that I am arguing should attend surveillance outside FISA, the Fifth Circuit has held, in the context of a search by Customs officials, that a "warrantless seizure or search in the complete absence of authority -- a lawless governmental intrusion -is unconstitutional per se." United States v. Williams, 617 F.2d 1063, 1074 (5 ${ }^{\text {th }}$ Cir. 1980) (en banc). The D.C. Circuit has criticized that holding. See United States v. Gonzalez, 875 F.2d 875, 877-78 (D.C. Cir. 1989); see also Barwood v. District of Columbia, 202 F.3d 290, 294 (D.C. Cir. 2000) (rejecting argument that arrests under ultra vires state law would automatically violate Fourth Amendment). 
justified by a genuine national security emergency. ${ }^{188}$ Furthermore, FISA has some requirements that are not related to enforcing the Fourth Amendment. ${ }^{189}$ The government should be able to show that surveillance that violates FISA nonetheless satisfies the Fourth Amendment because the violation is only technical or insubstantial. If the government cannot make this showing, however, the courts should find surveillance outside FISA to be also outside the Fourth Amendment. By presuming the unconstitutionality of surveillance outside FISA, courts can defang the current NSA surveillance program by limiting surveillance largely to instances in which it is reasonably necessary to respond to genuine national security emergencies. ${ }^{190}$

IV. Conclusion Surveillance outside FISA presumptively violates the Fourth Amendment, except when the surveillance is justified by genuine national security emergency. Surveillance outside FISA that is justified by a genuine emergency not only satisfies the Fourth Amendment but also falls within the President's power even though the surveillance violates FISA. That is because FISA violates the separation of powers doctrine to the extent that FISA tries to forbids the President from taking measures that he or she reasonably believes necessary to respond to genuine

\footnotetext{
${ }^{188}$ See supra notes ____ and accompanying text. The government might also rely on exigencies not directly related to a national security emergency or on Fourth Amendment doctrines, besides the exigent circumstances doctrine, that allow warrantless searches. As a practical matter, however, these alternatives are not likely to arise often. Furthermore, as discussed above, neither the special needs doctrine nor the border search doctrine supports the NSA surveillance program as a whole. See supra note

${ }^{189}$ For example, FISA prescribes the contents of court orders authorizing surveillance. 50 U.S.C. $\S$ 1805(c). The prescribed contents include a judicial direction that officials "compensate, at the prevailing rate," anyone who helps officials accomplish the surveillance -- including the landlord who uses her passkey to open the apartment in which a telephone tap is to be placed. Id. § 1805(c)(2)(D). A surveillance order that omits this direction technically violates FISA, as does a surveillance operation in which a landlord assists without receiving compensation. Yet neither of these technical violations should lead to a conclusion that the surveillance violates the Fourth Amendment.

${ }^{190}$ As noted above, supra note _ , courts can presumably review surveillance under the NSA program when the government seeks to use evidence derived from such surveillance in criminal prosecutions. $C f$. United State v. Dumeisi, 424 F.3d 566, 578-79 (7th Cir. 2005) (reviewing district court's ruling on defendant's motion to suppress evidence derived from FISA surveillance). Judicial review may also be available in civil litigation challenging the program, though this remains to be determined. See Niraj Warikoo, Wiretap Suit All About Power, DetroIT FREE PRESS, June 13, 2006, at in ACLU V. NSA, supra note _ , in which government argues for dismissal). (reporting on hearing
} 
national security emergencies. The current NSA surveillance program also violates the Constitution, however, because it exceeds the President's congressionally irreducible power to respond to genuine national security emergencies.

As this summary show, the current situation involves unconstitutional conduct by the President (in authorizing NSA surveillance that is not justified by a genuine national security emergency) and by Congress (in enacting a statute, FISA, that in some instances infringes on the President's plenary powers under the Constitution). Beyond violating the Constitution, the President and Congress have created great legal uncertainty: Congress says one thing in FISA, the President is doing another in the NSA program. Thus, the surveillance law on the books differs from the surveillance law "on the streets." This is no way to fight a war on terrorism.

Most supporters and opponents of the NSA program now appear to agree on the need to make the surveillance law on the books congruent with the surveillance law on the streets. A similar consensus produced FISA. ${ }^{191}$ As with FISA, new legislation will be contentious and take time. As with FISA, the contentiousness surrounding new legislation stems from the need to strike two difficult balances: (1) the balance between national security and "the right of the people to be secure in their persons, houses, papers, and effects, against unreasonable searches, and seizures"192; and (2) the balance between the President's power and Congress's power to strike that first balance. Even rancorous and protracted debate on those issues is better than the current situation.

This article seeks to contribute to the debate in two ways. First, it sheds light on a connection that has not received enough attention: the connection between the President's power to defy an Act of Congress and Fourth Amendment limits on that power. Second, in exploring that connection, the article offers an analysis that is more nuanced, and stakes out a more moderate position, than those offered by most opponents and supporters of the current

\footnotetext{
191 See Seamon \& Gardner, supra note legislative history).

192 U.S. CONST. amend. IV. , at 336-37 \& nn. 66-71 (2005) (discussing and citing relevant
} 
NSA program. The separation of powers analysis offered here neither denies the existence of congressionally irreducible power in the President nor supports the President's disregard of generally valid legislation. Similarly, the Fourth Amendment analysis offered here recognizes Congress's authority to enforce the Fourth Amendment without treating that authority as absolutely binding on the executive branch or the courts. It is hoped that principled legal analysis will facilitate principled and politically feasible proposals for legislative reform. 